No. 21-1

\title{
How to Design a State Education Aid Formula That Is Equitable, Adequate, and Politically Feasible: The Case of Connecticut
}

\section{Bo Zhao}

\begin{abstract}
:
After being sued for inequity and inadequacy in school funding, many states have reformed their education aid policies. Using Connecticut as an example, this paper shows how to design a state education aid formula that can effectively address funding inequity and inadequacy while taking political feasibility into account. It first develops a measure of the gap between education cost and revenue capacity, both of which are estimated using school district characteristics that are outside the direct control of local officials at any given point in time. It then uses each district's cost-capacity gap to evaluate the state's existing education aid distribution. This paper shows that while larger-gap districts, on average, receive greater amounts of state aid per pupil under Connecticut's existing distributions, significant inequity and inadequacy remain. This paper proposes, as a potential solution, a gap-based formula that allocates state aid to close the cost-capacity gaps. The formula includes tools such as minimum and maximum levels of aid to increase its political appeal. The research method and the formula design that this paper presents are sufficiently general and flexible to be adapted easily and applied to other states.
\end{abstract}

JEL Classifications: H75, I21, I22, I28

Keywords: education cost, revenue capacity, state education aid, aid formula

Bo Zhao is a senior economist in the Federal Reserve Bank of Boston Research Department. His email is Bo.Zhao@bos.frb.org.

The author thanks Jeff Thompson and participants at the Federal Reserve Bank of Boston Research Department's Brown Bag Seminar for helpful comments. Lan Ha provided excellent research assistance.

This paper presents preliminary analysis and results intended to stimulate discussion and critical comment. The views expressed herein are those of the author and do not indicate concurrence by the Federal Reserve Bank of Boston, the principals of the Board of Governors, or the Federal Reserve System.

This paper, which may be revised, is available on the website of the Federal Reserve Bank of Boston at http://www.bostonfed.org/economic/wp/index.htm. 


\section{Introduction}

Concerns about the equity and the adequacy in public school finance are deep seated and long running in the United States. These concerns stem from the combination of school funding's traditionally heavy reliance on local property taxes and a significant variance in per-pupil property wealth across school districts. Low-income students and other students with greater learning needs often live in property-poor districts due to income and racial segregation. As a result, propertypoor districts not only have fewer of their own resources, they also have greater student need compared with their wealthier counterparts.

Almost every state in the country has been sued over school funding in the past half century. ${ }^{1}$ Between 1973 and 2019, ${ }^{2}$ lawsuits were filed in 47 states $;{ }^{3}$ Hawaii, ${ }^{4}$ Nevada, and Utah were the exceptions. In the earlier lawsuits, plaintiffs often argued that equal protection clauses in their state constitutions guarantee equal per-pupil school funding across the state, regardless of school districts' property wealth. In the later lawsuits, however, plaintiffs often resorted to provisions in state constitutions that guarantee all students an "adequate," "sound basic," or "thorough and efficient" education. Many plaintiffs interpreted an "adequate education" to mean providing every school district with sufficient resources to meet a student test performance target and/or high school graduation standards that states implemented as part of school accountability policies.

\footnotetext{
${ }^{1}$ See http://schoolfunding.info/ for more information about each state's litigation history.

${ }^{2}$ In 1973, the U.S. Supreme Court ruled against plaintiffs in San Antonio Independent School District v. Rodriguez, stating that the U.S. Constitution does not guarantee education as a "fundamental interest." Since then, the battlefield has shifted to the state level, with litigations filed in the state courts.

${ }^{3}$ Iowa is a special case. In 2004, the state reached a settlement with the plaintiffs that resulted in the lawsuit being withdrawn without prejudice.

${ }^{4}$ Hawaii has a unique public school system: The entire state is a single school district. Therefore, funding disparities across districts do not exist.
} 
State court decisions on these cases have been mixed so far. Courts ruled in favor of the plaintiffs in 26 states and in favor of the defendants (the states) in 21 states. Some states-including Arizona, California, Connecticut, Minnesota, and Texas — have seen both plaintiff and defendant victories since 1973. As of March 2020, court cases on school funding were pending in 14 states. In addition, states that currently have no pending cases could be sued in the future. Therefore, how to design an equitable, adequate, and politically feasible school funding system remains a relevant and important policy issue for many, if not all, states.

This paper uses Connecticut as the subject of a case study. To a large extent, Connecticut exemplifies states that have highly inequitable school funding systems and have long struggled to meet the equity-and-adequacy mandate. Connecticut's public school system relies heavily on local property taxes as a funding source. According to the U.S. Census Bureau's 2017 Annual Survey of School System Finances, local revenues-mostly property taxes—accounted for 58 percent of public school funding in Connecticut. This was the fourth-highest percentage in the nation. Despite having the highest per capita income and the fifth-highest median household income among the 50 states in 2018, Connecticut had the second-highest income inequality that year, as measured by the Gini Index (Guzman 2019).

One of the first states sued in the 1970s over the constitutionality of its school funding system, Connecticut has faced multiple lawsuits over the years. Its state courts have delivered mixed rulings, declaring plaintiff victories in some cases and state defendant victories in other cases. In the most recent case (Connecticut Coalition of Justice in Education Funding v. Rell), which was first filed in 2005, the Connecticut Superior Court ruled against the state in 2016, but the state's highest court overturned that ruling in 2018. 
In response to these lawsuits and court rulings, Connecticut's state legislature has reformed the state education aid system several times. In 1988, it established the Education Cost Sharing (ECS) formula as a main mechanism for distributing state education grants. Since then, the legislature has periodically made major changes to the formula. ${ }^{5}$ Like the previous ECS formulas, the most recent one, adopted in 2017, has been criticized for not deriving from data analysis and not being based on a student performance level (Connecticut School Finance Project 2019). Many policymakers, practitioners, and advocacy groups have called for a reexamination and improvement of the ECS formula. ${ }^{6}$

This paper makes several contributions to the academic literature and current policy discussions. To the best of my knowledge, it is the first study to calculate the cost-capacity gap as a summary measure of the inequity and inadequacy in Connecticut's school finance. The costcapacity gap is defined as the difference between education cost and revenue capacity, both of which I estimate based on factors outside the direct control of local officials at any given point in time. In particular, I derive education cost from a cost regression, and it is conditional on a common student test performance target and efficiency level across school districts. I then use the gap measure to evaluate how effectively the distribution of Connecticut's existing education grants addresses the inequity and inadequacy among school districts.

More importantly, this paper is the first study to design a gap-based formula to improve Connecticut's education aid distribution. It provides the state with a menu of policy options to increase the formula's political feasibility, including a minimum and/or maximum level of aid and

\footnotetext{
${ }^{5}$ Due to lack of funding, the state did not run the ECS formula and instead distributed the ECS grants via block grants from FY2010 through FY2018 (Connecticut School Finance Project 2018).

${ }^{6}$ House Bill 7355, "An Act Concerning a Study of the Education Cost Sharing Formula," was filed in the 2019 regular session of the Connecticut General Assembly. It generated media attention but was eventually tabled for that year's House calendar.
} 
a provision that holds existing aid harmless. This paper uses policy simulations to demonstrate the tradeoffs between equity, adequacy, and political feasibility, as well as state financial requirements. It also shows differential effects of implementing a gap-based formula on different types of school districts. The research approach and the formula design used in this paper are sufficiently general to be applicable to other states.

\section{Overview of Connecticut's Main Education Aid Formula}

Connecticut currently has 11 education funding formulas (Connecticut School Finance Project 2019). ${ }^{7}$ The most important one is the ECS formula, which determines the allocation of the largest category of state education aid: the ECS grants. The state uses the other formulas to allocate a small amount of state aid that helps to fund charter schools, magnet schools, and regional vocational schools.

The ECS formula has retained the same basic structure since it was created in 1988 . Following a pupil-based "foundation" model that has been widely used across the United States, the ECS formula is structured as follows:

$$
(\text { ECS target aid })_{i t}=\text { foundation }_{t} \times(\text { total need students })_{i t} \times(\text { base aid ratio })_{i t}+
$$$$
\text { (regional bonus })_{i t} \text {. }
$$

ECS target aid is the ECS grant amount that each city or town should receive in each fiscal year if the state fully funds the ECS grant program. Each city or town is required by state law to pass all of its ECS grant funds to the local board of education, which is fiscally dependent on the city or town government. Foundation is intended to represent the cost of educating a typical Connecticut

\footnotetext{
${ }^{7}$ Not all state funding for public K-12 education is formula based. For example, the Excess Cost grant, which the state uses to help pay extraordinary special education costs, is allocated through expense reimbursements to school districts.
} 
public school student who does not have any additional learning needs. Total need students is a weighted enrollment measure, with extra weights given to pupils with additional learning needs (for example, low-income students). Therefore, the product of foundation and total need students is intended to represent the total education cost for each city or town in each year. Base aid ratio, which is also called state aid percentage, is the share of each city or town's total education cost that is funded by the ECS grants in each year. It is set to be lower for cities and towns with more wealth, subject to a minimum percentage. Regional bonus is awarded to members of regional school districts, with $\$ 100$ per regional-school student scaled by the ratio of the number of grades in the regional school district to 13 .

While this formula structure has remained intact, the way that the state calculates the components of the ECS formula has changed numerous times. Under the current formula, which was introduced in October 2017, the state gives low-income and English-learner students extra weights in calculating the number of total need students: ${ }^{8}$

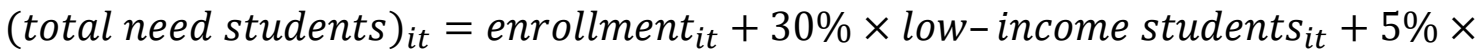

$$
\begin{aligned}
& \left(\text { low-income students }_{i t}-75 \% \times \text { enrollment }_{i t}\right) \times I\left(\text { low-income }_{\text {students }} \text { it } \geq 75 \% \times\right. \\
& \text { enrollment } \left._{i t}\right)+15 \% \times \text { English learners }_{i t} \text {. }
\end{aligned}
$$

Low-income students are defined as students who are eligible for free or reduced-priced meals or free milk (often abbreviated as FRPL). If a city or town has a high concentration of low-income students, which is defined as 75 percent or more of the total number of students being eligible for

\footnotetext{
${ }^{8}$ See the appendix for the various ECS formulas used during the period from FY2008 to FY2017. For more information about the history of school finance in Connecticut, see Connecticut School Finance Project (2018).
} 
FRPL, I (low-income students lit $\geq 75 \% \times$ enrollment $\left._{i t}\right)$ is equal to 1 ; otherwise it is equal to 0.

In calculating the base aid ratio under the current formula, the state accounts for both taxable property value and residents' income to measure each city's or town's relative wealth:

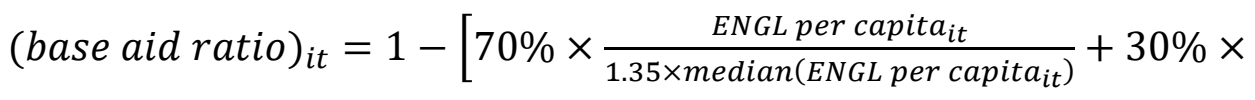

$$
\begin{aligned}
& \left.\frac{\text { median household income } i t}{\left.1.35 \times \text { median(median household income } e_{i t}\right)}\right] \text {. }
\end{aligned}
$$

$E N G L$ is an abbreviation of "equalized net grant list," which refers to the full fair market value of taxable properties after state adjustments for differences in assessment quality across cities and towns. Median(ENGL per capita $i t$ ) and median(median household income $_{i t}$ ) are the median values of ENGL per capita and median household income across Connecticut cities and towns. In addition, the state gives an extra 3 to 6 percentage points as a bonus to 19 cities and towns to raise their base aid ratios. ${ }^{9}$ The state has also established a minimum base aid ratio, which is 10 percent for the 33 cities and towns that it classifies as Alliance Districts and 1 percent for all other cities and towns. ${ }^{10}$ Despite the above-mentioned changes, the state has kept the foundation amount at \$11,525 per pupil since fiscal year 2014 .

The current ECS formula has several shortcomings (Connecticut School Finance Project 2019). First, the foundation amount is not derived from verifiable school spending data and is not

\footnotetext{
${ }^{9}$ The state selects these 19 cities and towns because they have the highest values of the Public Investment Community Index. The index is intended to measure the relative wealth and need of Connecticut's cities and towns based on per capita income, adjusted equalized net grand list per capita, equalized mills rate, per capita aid to children receiving Temporary Family Assistance benefits, and unemployment rate. For more information about the Public Investment Community Index, see https://portal.ct.gov/OPM/IGPP-MAIN/Services/Public-Investment-Community-Index.

${ }^{10}$ The state designates the 33 lowest-performing school districts as Alliance Districts and requires them to submit plans for using a portion of their ECS grants to increase student outcomes and close achievement gaps. For more information about the Alliance District program, see https://portal.ct.gov/SDE/Alliance-Districts/Alliance-Districts.
} 
based on any student performance level. Also, since the amount has not changed since FY2014, it may not have kept up with cost increases over time. Second, the factors and weights used in calculating the number of total need students and the base aid ratio are arbitrary and not derived from data analysis. Third, the validity of using FRPL to define low-income students has become increasingly questionable. The federal Healthy, Hunger-free Act of 2010 includes the Community Eligibility Provision (CEP), which allows all students to receive free meals if their school or district qualifies for and participates in the CEP. ${ }^{11}$ As a result, the CEP districts and schools no longer require parents to file the paper-form household applications for FRPL. However, the state still requires the CEP districts and schools to report the hypothetical FRPL status of students for the purpose of receiving state aid. The data are widely perceived as inaccurate, and the problem is expected to worsen over time as more schools and districts participate in the CEP. ${ }^{12}$

In addition, there are doubts about the state's long-term commitment to the new ECS formula. The current plan calls for a gradual increase in the ECS grants over a 10-year period to finally achieve the full funding in FY2028. Given that Connecticut has a long history of overriding the ECS formula when facing fiscal difficulties, many stakeholders and observers are unsure how long the state will adhere to this phase-in plan.

\section{Conceptual Framework of a New Gap-based Aid Formula}

To address the criticism of the ECS formula and improve the formula design in general, this section describes the conceptual framework of a new aid distribution formula based on the cost-capacity

\footnotetext{
${ }^{11}$ Districts and schools must have at least 40 percent of their students directly certified by the state for free meals in order to qualify for the CEP. The state utilizes administrative data to directly certify (1) students whose families participate in the Supplemental Nutritional Assistance Program (SNAP), Temporary Assistance for Needy Families (TANF), or Medicaid for children, and (2) students in other categorically eligible programs, such as homeless, runaway, migrant, foster care, and Head Start programs.

${ }^{12}$ The state instructs the CEP districts and schools to infer the FRPL status of each student from direct certification, the preceding year's FRPL data, and the "alternative income survey."

See https://portal.ct.gov/-/media/SDE/Digest/cep_memo_and_alt_inc_survey_08092014_2.pdf?la=en.
} 
gap, which is defined as education cost minus revenue capacity. This gap-based formula can help states approach the equity and adequacy goals more effectively, and it allows tools that can enhance its political feasibility.

\section{Education Cost}

In the school finance literature, education cost is usually defined as how much money a school district or school must spend at an assumed common efficiency level to achieve a specific student performance target given its students' learning needs. Because education cost is not directly observed, scholars often must estimate a cost function to derive a reliable and verifiable measure of education cost. ${ }^{13}$ The most common empirical approach is to regress the logarithm of current spending per pupil on the so-called cost factors, student performance, and proxy variables for efficiency while treating student performance as endogenous and instrumenting it with instrumental variables. Cost factors are characteristics approximating student learning needs and other cost drivers that are outside the direct control of local officials at any given point in time. For example, low-income students are likely to receive less support from parents and therefore have greater learning needs compared with high-income students.

Based on district-level data, a typical cost regression is specified as follows:

$$
\log E_{i t}=\alpha C_{i t}+\beta Q_{i t}+\gamma F_{i t}
$$

\footnotetext{
${ }^{13}$ See, for example, Downes and Pogue (1994), Duncombe, Ruggiero, and Yinger (1996), Duncombe and Yinger (1997, 1998, 1999, 2000, 2005a, 2005b, 2006, 2007, 2011 a, and 2011b), Imazeki (2001 and 2008), Duncombe (2002, 2006, and 2007), Duncombe, Lukemeyer, and Yinger (2003), Imazeki and Reschovsky (2003, 2004, and 2006), Reschovsky and Imazeki (2003), Gronberg et al. (2004), Gronberg, Jansen, and Taylor (2011), and Baker et al. (2018). Given the considerable differences in fiscal institutions and data availability across states, scholars tend to focus on a single state in each of their studies. Nevertheless, there are exceptions, such as Baker et al. (2018), which use national pooled data.
} 
where $E_{i t}$ is current spending per pupil for district $i$ in year $t, C_{i t}$ is cost factors, $Q_{i t}$ is student performance (for example, state-administered standardized test results and/or high school graduation rate), and $F_{i t}$ is variables that can be conceptually linked to district efficiency (see Duncombe and Yinger 2011a). This regression is often estimated using 2SLS, with student performance $Q_{i t}$ instrumented with instrumental variables. Based on the regression results, education cost can be calculated as ${ }^{14}$

$$
\widehat{E}_{i t}=e^{\left(\alpha C_{i t}+\beta \bar{Q}_{t}+\gamma \bar{F}_{t}\right)}
$$

where $C_{i t}$ takes the actual values of cost factors for district $i$ in year $t, \bar{Q}_{t}$ is fixed at a state-set common student performance target, and $\bar{F}_{t}$ is typically set to be the enrollment-weighted statewide average values to ensure that the average efficiency level is applied to all districts. ${ }^{15}$

By design, this cost measure has several desirable features. It is based on cost factors that are outside the direct control of local officials at any given point in time. Since each district's efficiency level is held at the same hypothetical level, differences in education cost across school districts are not affected by individual districts' actual efficiency levels. Therefore, this measurement approach does not reward less efficient districts or penalize more efficient districts.

\footnotetext{
${ }^{14}$ An alternative and mathematically equivalent way to calculate education cost involves two steps. In the first step, researchers calculate a cost index, which is a ratio of a school district's predicted spending per pupil to that of a hypothetical average school district while all variables other than the cost factors in the regression are held constant. The hypothetical average district is commonly defined as a school district with the enrollment-weighted statewide average values of the cost factors and all other variables. Because all other variables are held constant, they are cancelled out from the numerator and denominator of the cost index, and only the cost factors affect the index. In the second step, researchers use this cost index to scale up or down the hypothetical average district's education cost to obtain each district's education cost. The hypothetical average district's education cost is assumed to equal the predicted spending when its efficiency level is set to equal the statewide average efficiency level and its student performance is set to equal a common student performance target.

15 The state can use the assumed common level of district efficiency as a policy lever to influence the calculated education cost and therefore ultimately affect state funding responsibility for schools. For example, the state could choose the $25^{\text {th }}$ percentile value from the statewide distribution of $\gamma F_{i t}$, which means that every district is assumed/expected to operate at the top 25 percent efficiency level instead of the statewide average efficiency level. When the state assumes a higher common efficiency level, the resulting measure of education cost for each school district will be lower than it would be otherwise.
} 
In addition, unlike the foundation amount in the ECS formula, which is not linked to any student performance level, this cost measure is based explicitly on a common student performance target. The higher the target, the greater the education cost. Because the target is a policy lever, the state can raise or lower it to change the state's financial commitment to public K-12 education.

\section{Revenue Capacity}

Revenue capacity is defined as the underlying ability of local government to raise revenue outside state revenue transfers. ${ }^{16}$ In the case of Connecticut and other New England states, school districts are not authorized to impose their own taxes and instead depend fiscally on their home-city or hometown governments. Therefore, in these states, the revenue capacity of a district to fund public $\mathrm{K}-12$ education actually refers to the revenue capacity of that district's hometown (or towns for regional school districts). Like education cost, revenue capacity is not directly observed and must be estimated.

The literature describes two primary approaches to measuring revenue capacity. The first is called the Representative Tax System (RTS), which the Advisory Commission on Intergovernmental Relations developed in the early 1960s (Advisory Commission on Intergovernmental Relations 1962). Under this approach, revenue capacity is estimated as the amount of money that a government would be able to raise from its tax base at a "standard" tax rate. The standard tax rate is intended to represent a typical tax effort level of local government. To put it mathematically,

$$
\hat{R}_{i t}=\bar{\tau}_{t} B_{i t}
$$

\footnotetext{
${ }^{16}$ School districts also receive federal grants, which tend to be small and earmarked for special purposes. Local governments have no direct control over the federal grant amounts. Therefore, researchers usually add the amount of the federal grants directly to each district's revenue capacity measure.
} 
where $\hat{R}_{i t}$ is the estimated revenue capacity per pupil for district $i$ in year $t, \bar{\tau}_{t}$ is the standard tax rate that is applied to all localities, and $B_{i t}$ is the size of the local tax base per pupil.

By design, this revenue capacity measure is directly proportional to the size of the local tax base, regardless of how heavily each local government actually taxes its base. Therefore, this approach avoids penalizing or rewarding local governments for having a relatively high or low tax effort, respectively. In addition, the state government can use the standard tax rate as a policy lever to change local (and therefore state) funding responsibility for public services.

The second approach to measuring revenue capacity is the "income-with-tax-exporting" method developed by Ladd and Yinger (1989). Under this approach, revenue capacity is estimated as the amount of money that a government would be able to raise from local residents under a "standard" tax burden and from nonresidents who eventually pay a portion of local taxes. The standard tax burden is intended to represent a typical percentage of local residents' incomes used to pay local taxes. Similar to the standard tax rate in the RTS approach, the standard tax burden is a policy lever set by policymakers. Presented mathematically, under the income-with-taxexporting approach, revenue capacity per pupil is calculated as

$$
\hat{R}_{i t}=\bar{k}_{t} Y_{i t}\left(1+\hat{e}_{i t}\right)
$$

where $\bar{k}_{t}$ is the standard tax burden that is applied across localities, $Y_{i t}$ is local residents' income per pupil, and $\hat{e}_{i t}$ is the tax export ratio, which is defined as the amount of the taxes paid by nonresidents for every dollar of the taxes paid by local residents. Estimating the tax export ratio is empirically challenging. Researchers almost unavoidably make simplifying, but questionable, assumptions about who (residents versus nonresidents) bears what share of each type of local taxes (for example, property tax, sales tax, or income tax, if any). 
In the context of examining local non-school fiscal disparities, Ladd, Reschovsky, and Yinger (1991) and Zhao (2018) compare the two approaches using Minnesota and Connecticut data, respectively. Both studies find that the capacity measures calculated from the two approaches are highly correlated with each other; the relative positions of localities in terms of their capacity measures are similar under both approaches. That being said, the measure calculated from the income-with-tax-exporting approach shows smaller variation across localities compared with the measure calculated from the RTS approach. This is mostly because resident income is more evenly distributed than the property tax base across localities.

Researchers, practitioners, and policymakers usually prefer the RTS approach to the income-with-tax-exporting approach. Downes and Pogue (1992) suggest that the RTS approach is particularly more suitable for calculating revenue capacity as an input of state aid formulas. It would help to equalize local tax rates across the state to fund a given level of local public services and therefore equalize local competitiveness in attracting population and firms, which is not what the income-with-tax-exporting approach intends to do. In addition, the RTS approach is easier to understand and implement and therefore has been used more widely and frequently in practice.

\section{Cost-capacity Gap}

The cost-capacity gap is the difference between education cost and revenue capacity. Therefore, it is calculated simply as

$$
\widehat{G}_{i t}=\widehat{E}_{i t}-\widehat{R}_{i t}
$$

where $\widehat{G}_{i t}, \widehat{E}_{i t}$, and $\hat{R}_{i t}$ are the estimated cost-capacity gap, education cost, and revenue capacity per pupil, respectively, for district $i$ in year $t$. Substituting $\widehat{E}_{i t}$ and $\hat{R}_{i t}$ with equations (5) and (6) results in

$$
\widehat{G}_{i t}=e^{\left(\alpha C_{i t}+\beta \bar{Q}_{t}+\gamma \bar{F}_{t}\right)}-\bar{\tau}_{t} B_{i t}
$$


This gap measure shows how much money a school district needs beyond its own revenue capacity to adequately fund the education cost required for reaching the student performance target. The larger the gap, the greater the need for external financial assistance. As equation (9) shows, differences in the gap measure stem from disparities across districts in cost factors and the tax base, both of which are outside the direct control of local officials at any given point in time. Nevertheless, state policymakers can affect the absolute size of the calculated gap measure by changing the policy variables: the student performance target, the common district efficiency level, and the standard tax rate.

\section{Gap-based Aid Formula}

To achieve full funding equity and adequacy, the state should use education aid to close each district's cost-capacity gap. That is,

$$
A_{i t}=\hat{G}_{i t},
$$

where $A_{i t}$ is state education aid per pupil for district $i$ in year $t$. By doing so, the state could ensure that all school districts have adequate funding to cover the education cost required to achieve the common student performance target.

In reality, this formula is not feasible without taking politics into consideration. Because any new formula has to be approved by the state legislature, it must gather as much support from lawmakers as possible. One challenge in implementing the gap-based formula as formulated in equation (10) is that it indicates districts with negative cost-capacity gaps would receive negative state aid, meaning that they would send money to the state instead of receiving money from the state. This outcome is unlikely to be acceptable for these districts. Furthermore, districts with small positive cost-capacity gaps may also withhold their support for this formula if they deem the gapbased aid amounts that they would receive too small. In addition, the gap-based formula would 
award large amounts of state aid to school districts with large positive cost-capacity gaps, which could potentially create disapproval from other districts.

This formula may also require significant financial resources from the state, which could potentially drain the state budget and crowd out state funding for other priorities. Moreover, the requirement of extraordinary financial commitment would make it difficult for the state to adhere to the gap-based formula in the long run. It is a particularly serious concern for a state such as Connecticut, which has a long history of bypassing the statutory education aid formula when facing revenue shortfalls.

To increase the political feasibility of the gap-based aid formula, policymakers can modify it by incorporating tools such as a minimum aid level, a maximum aid level, and/or a full or partial hold-harmless provision. A full hold-harmless provision would guarantee that no district receives less aid than 100 percent of what it received the preceding year. A full or partial hold-harmless could be considered a special case in which the minimum aid is defined as 100 percent or less, respectively, of the preceding year's aid. Taking these tools into account, the gap-based aid formula can be modified into

$$
A_{i t}=\left\{\begin{array}{lr}
A_{H t} & \text { if } \hat{G}_{i t}>A_{H t} \\
\hat{G}_{i t} & \text { if } A_{L t} \leq \hat{G}_{i t} \leq A_{H t} \\
A_{L t} & \text { if } \hat{G}_{i t}<A_{L t}
\end{array}\right.
$$

where $A_{H t}$ and $A_{L t}$ are the maximum aid and the minimum aid, respectively. By design, the maximum aid and minimum aid primarily deal with the two tails of the gap distribution.

While implementing these tools can broaden political support for the gap-based formula, they do come with social and economic costs. With the maximum-aid cap, the largest-gap districts would not receive adequate funding to reach the student performance target, even though they are 
the ones that need help the most. On the other hand, districts receiving the minimum aid would have more than enough to close their cost-capacity gaps. Therefore, using these tools would prevent the state from fully accomplishing the equity and adequacy goals. In addition, including the minimum aid would place a greater financial burden on the state compared with using a pure gap-based formula without the minimum aid.

In the next three sections, I use Connecticut as a case study to show how this cost-capacity gap framework can be applied in practice. The first section demonstrates how to use data to calculate the cost-capacity gap for each Connecticut school district and analyze the gap distribution. The second section uses this gap measure to evaluate the effectiveness of the existing aid distribution in addressing the inequity and inadequacy in Connecticut school finance. The third section conducts policy simulations of implementing a gap-based formula with or without the minimum aid and maximum aid. It examines the implications of including the minimum aid and maximum aid for equity, adequacy, and demand for state financial resources.

IV. Calculating and Analyzing the Cost-capacity Gap for Connecticut School Districts

This paper develops the education-cost measure for each Connecticut school district based on results from Zhao (2020). Using district-level data from FY2009 through FY2013, Zhao (2020) runs a cost regression similar to equation (1) and identifies four cost factors (Table 1). The first two cost factors are the percentage of school-age children (aged 5 through 17) from families living in poverty and the percentage of students living in single-parent or non-family households. ${ }^{17}$ Students who live in low-income, single-parent, or non-family households are likely to receive less support from their parents and therefore need more assistance from schools to achieve the

\footnotetext{
${ }^{17}$ Zhao (2020) prefers the percentage of school-age children from families living in poverty to the percentage of students eligible for FRPL as a measure of low-income students, because the former has not been affected by the CEP, while the latter has.
} 
same performance level as other students. The third cost factor is the size of the district. Small districts, defined as having fewer than 2,000 enrolled students, are unable to capture the economies of scale that benefit larger districts. ${ }^{18}$ The last cost factor is whether or not a school district is a regional district. A regional district may incur additional costs related to coordination among the member towns.

Following equation (5), I calculate the predicted cost per pupil for each Connecticut district in FY2013 under the following assumptions. First, I set the efficiency-related variables to equal the enrollment-weighted statewide average values in FY2013 for all districts. ${ }^{19}$ In doing so, I essentially hold each district's efficiency at the same statewide average level for that year. ${ }^{20}$ Second, I set the student performance level of each district to be the same pre-selected target: 90 percent of students reaching or exceeding the proficiency level in the state-administered math, reading, and writing tests. ${ }^{21}$ This target is higher than the enrollment-weighted statewide average student test performance level in FY2013, which was about 83 percent of students reaching or exceeding the proficiency level. These assumptions are made for the purpose of illustration; policymakers can adjust them according to their objectives. For example, the state can choose a lower student performance target and/or a higher common level of district efficiency, which will

\footnotetext{
${ }^{18}$ One may argue that the state could change the district size by requiring small districts to consolidate. However, before such a state-level mandate is implemented, the district size is still outside the direct control of local officials at any given point in time. In addition, the regression results in Zhao (2020) suggest that, on average, school district consolidation would not produce net cost savings. The estimated coefficient on the dummy variable for an enrollment of fewer than 2,000 students is slightly less than the estimated coefficient on the dummy variable for a regional school district (Table 1).

${ }^{19}$ I include fixed effects for labor market areas and years in the efficiency-related variables, since they control for unobserved efficiency differences across labor market areas and between years.

${ }^{20}$ I also calculate the predicted cost when each district's efficiency is held at the statewide top 25 percent level. These results are available upon request.

${ }^{21}$ I also calculate the predicted cost under three other hypothetical targets: 95 and 100 percent as well as the enrollment-weighted statewide average percentage of students reaching or exceeding the proficiency level. These results are available upon request.
} 
result in a lower predicted cost for each district and ultimately a smaller amount of needed state education aid.

To make this analysis more current and relevant to policymakers, I then use the Consumer Price Index for the Northeast region to inflate the FY2013 predicted cost per pupil to the FY2019 value. The real value of education cost is likely relatively stable, because the input variables in equation (5), especially the cost factors, are slow moving.

However, the student performance target underlying the predicted cost measure needs to be reinterpreted, because the state changed the standardized tests from the Connecticut Mastery Test (for students in grades 3 through 8) and the Connecticut Academic Performance Test (for students in grade 10) to the Smarter Balanced test (for students in grades 3 through 8 and grade 11) in 2015. To translate student performance under the old test regime to performance under the new regime, I run a univariate regression with a constant term:

$$
Z_{i t}=\rho Q_{i t-6}+\theta
$$

where $Z_{i t}$ is the average percentage of tested students meeting or exceeding the achievement standard in math and English language arts (ELA) under the Smarter Balanced test for district $i$ in year $t ; Q_{i t-6}$ is the average percentage of tested students reaching or exceeding the proficiency level in math, reading, and writing under the Connecticut Mastery Test and the Connecticut Academic Performance Test for district $i$ in year $t-6$; and $t=2015,2016, \ldots, 2019$. I run a weighted regression using enrollment as the weight to account for size differences across school districts. ${ }^{22}$

This regression shows a tight relationship between student performance measured by the Smarter Balanced test and student performance measured previously by the Connecticut Mastery

\footnotetext{
${ }^{22}$ The unweighted regression produces results similar to those of the weighted regression.
} 
Test and the Connecticut Academic Performance Test. The adjusted R-squared of the regression is 0.88 . The estimated coefficients are highly significant, with $\hat{\rho}=1.40$ and $\hat{\theta}=-64.41$.

Based on this regression, I use the statewide average student performance in FY2013which is 82.68 percent of tested students reaching or exceeding the proficiency level—to predict the FY2019 student performance. The predicted value for FY2019 is 51.3 percent, which almost perfectly matches that year's statewide average student performance of 51.9 percent of tested students meeting or exceeding the achievement standard. Similarly, according to this regression, 90 percent of tested students reaching or exceeding the proficiency level in FY2013 corresponds to 61.5 percent of tested students meeting or exceeding the achievement standard in FY2019. Therefore, the FY2019 cost - which derives from the FY2013 cost under the target of the 90 percent proficiency — can be interpreted as the cost for having 61.5 percent of tested students meeting or exceeding the achievement standard.

To estimate revenue capacity for each Connecticut school district, I use both the RTS approach and the income-with-tax-exporting approach and then compare the results. In applying the RTS approach, I first define the local tax base as the value of taxable property (that is, ENGL), because property tax is virtually the only local tax allowed in Connecticut.

Second, I select the standard tax rate by directly linking it to how the responsibility of funding public schools is divided between the state and local governments. I assume that statewide property taxes collected at this standard tax rate are just sufficient to fund a pre-determined local share of statewide predicted costs. Under this assumption, the standard tax rate can be calculated as

$$
\tau_{t}=\frac{L_{t} \sum_{i}\left(\hat{E}_{i t} N_{i t}\right)}{\sum_{i}\left(B_{i t} N_{i t}\right)},
$$


where $L_{t}$ is the pre-determined local share between 0 and 1 , and $N_{i t}$ is the enrollment for district $i$ in year $t$. The local share, $L_{t}$, is a policy variable for the state. The higher the local share (which lowers the state's funding responsibility), the higher the standard tax rate for cities and towns. ${ }^{23}$ For the purpose of illustration, I assume the local share is 55 percent. ${ }^{24}$ It is close to the 56 percent share of statewide current spending of school districts funded by local revenue during the 20092013 period. ${ }^{25}$ Under the local share of 55 percent and the target of having 61.5 percent of tested students meeting or exceeding the achievement standard, the standard tax rate would be 0.92 percent for FY2019. Then using equation (6), I calculate the property tax capacity per pupil for each Connecticut school district.

In applying the income-with-tax-exporting approach, I first estimate the tax export ratio under two simplifying assumptions about the property tax incidence. Following Ladd (1994), I assume that (1) property taxes on taxable residential and personal properties are ultimately and entirely paid by local residents (that is, no tax exportation), and (2) property taxes on taxable commercial, industrial, and other business properties are ultimately and entirely paid by nonresidents (that is, 100 percent tax exportation). Under these assumptions, the tax export ratio is calculated as business ENGL divided by residential and personal ENGL, which ranges from 0.01 to 1.08 across Connecticut districts for FY2019.

\footnotetext{
${ }^{23}$ As equation (12) suggests, the standard tax rate is also affected by the student performance target, because the target is an input of the predicted cost $\hat{E}_{i t}$. The higher the student performance target (which increases the predicted cost), the higher the standard tax rate for cities and towns.

${ }^{24}$ I also calculate revenue capacity under two other hypothetical local shares: 50 and 60 percent. These results are available upon request.

${ }^{25}$ The amount of local revenue used to fund current spending of school districts is calculated as current spending minus revenue transfers from the state and federal governments. Following the literature, I remove transportation and food expenses from current spending of school districts because they do not directly contribute to the education production. Similarly, I remove state and federal grants earmarked for food, transportation, and capital projects.
} 
Similar to how I select the standard tax rate under the RTS approach, I select the standard tax burden by assuming statewide property taxes collected under this standard tax burden to be just sufficient to fund a pre-determined local share of statewide predicted costs. To make the results comparable with those from the RTS approach, I also assume the local share is 55 percent and the student performance target is 61.5 percent of tested students meeting or exceeding the achievement standard. As a result, the standard tax burden on local residents' income would be 2.6 percent for FY2019. Then, using equation (7), I calculate the property tax capacity per pupil for each Connecticut school district.

Figure 1 compares the measures of property tax capacity calculated from the two approaches for each Connecticut school district in FY2019. As the linear regression line indicates, the two measures are highly correlated with each other, with the enrollment-weighted correlation being 0.83 and significant at the 1 percent level. Nevertheless, the two measures are numerically not the same, as school districts scatter on either side of the 45-degree line. In addition, the capacity measure calculated from the RTS approach shows a wider range compared with the range calculated from the income-with-tax-exporting approach. Table 2 further confirms that the capacity measure calculated from the RTS approach has larger disparities across districts compared with the capacity measure calculated from the income-with-tax-exporting approach.

Given that the relative positions of most districts remain similar regardless of which approach is used, and that it is easier for policymakers to understand and implement the RTS approach, I follow the majority of the literature and use the RTS approach instead of the incomewith-tax-exporting approach to measure property tax capacity throughout the rest of the paper. The results from the income-with-tax-exporting approach are available upon request. 
On top of property tax capacity, I add two other revenue sources to account for the revenue capacity of Connecticut school districts. First, I add the federal grants that each school district received in FY2019. ${ }^{26}$ Federal grants are outside the direct control of local officials. They are relatively small, accounting for less than 5 percent of Connecticut school districts' current spending. Second, I add state payments on behalf of school districts for employees' retirement benefits in FY2019. In Connecticut, the state is responsible for the entire employer's contribution to the teachers' pension fund. It also contributes to the teachers' post-retirement health insurance fund. These state payments for teachers' retirement benefits are counted as both state revenue transfer and part of each school district's current spending in the Common Core of Data, on which the cost regression is based. ${ }^{27}$ Therefore, they are embedded in the calculated cost measure and need to be accounted for on the revenue capacity side. In summary, each school district's revenue capacity, excluding state education grants, is a sum of property tax capacity, federal grants, and state payments on behalf of school districts for employees' retirement benefits.

Table 3 shows that Connecticut's disparities in revenue capacity across school districts are greater than its disparities in education cost. Even more concerning is the significant mismatch between education cost and revenue capacity (Figure 2). School districts with the highest predicted cost per pupil tend to have the lowest revenue capacity per pupil. The enrollment-weighted correlation between the predicated cost and revenue capacity is -0.44 and statistically significant at the 1 percent level.

\footnotetext{
${ }^{26}$ I exclude federal grants earmarked for food, transportation, and capital projects, since expenditures on food, transportation, and capital projects are excluded from the current spending data for the cost regressions and therefore not accounted for in the cost measure.

${ }^{27}$ The Connecticut Teachers' Retirement Board publishes the annual aggregate state contributions to the teachers' Retirement Fund and Health Fund. However, it does not break them down by school district. Because the state sets its contributions to these retirement plans as a statewide uniform percentage of school districts' payroll, I can use the ratio of each district's total salary to all districts' total salary to allocate the aggregate state contributions and derive state contributions for each school district.
} 
As a result, there is a wide distribution of the cost-capacity gap per pupil in Connecticut (Table 4). Districts with the highest child poverty rates or the lowest property wealth per pupil tend to have the highest cost-capacity gaps, because, on average, they have the highest predicted cost and the lowest revenue capacity. On the other hand, districts with the highest property wealth per pupil, on average, have a negative cost-capacity gap. ${ }^{28}$ In addition, the largest districts - those in the fifth quintile of enrollment size - tend to have the highest cost-capacity gaps, which is partly attributable to their having the highest average predicted costs per pupil.

\section{Evaluating Connecticut's Existing Education Aid Distribution}

This section uses the cost-capacity gap measure to examine Connecticut's existing education aid distribution. ${ }^{29}$ To the best of my knowledge, no research has used such a gap measure to quantify how effective Connecticut education aid is in achieving its goal of finance equity and adequacy. If state aid were distributed in a way that closed each school district's cost-capacity gap, all districts would have adequate funding to achieve the common student performance target, regardless of their different student learning needs and revenue-raising abilities. The larger the deviation of state aid from the gap (in either direction), the less effective it is in accomplishing the equity and adequacy goal.

Figure 3 shows state aid playing an equalizing role across Connecticut school districts in FY2019. ${ }^{30}$ As the linear regression line suggests, larger-gap districts tend to receive more state aid

\footnotetext{
${ }^{28}$ Districts in the third quintile of the school-age child poverty rate, on average, have a negative cost-capacity gap because this quintile includes Greenwich, which has extraordinarily high revenue capacity per pupil.

29 I exclude state aid earmarked for food, transportation, and capital projects, since expenditures on food, transportation, and capital projects are excluded from the current spending data for the cost regressions and therefore not accounted for in the cost measure.

${ }^{30}$ Appendix Figures 1 and 2 examine the relationships between state education aid and the predicated cost and revenue capacity, respectively, in FY2019. Appendix Figure 1 shows that school districts with larger predicted costs tend to receive more state aid per pupil. The enrollment-weighted correlation between the two variables is 0.92 and significant at the 1 percent level. Appendix Figure 2 shows that school districts with lower revenue capacity tend to receive more
} 
per pupil. The enrollment-weighted correlation between the two variables is 0.79 and significant at the 1 percent level. When I use the Kernel-weighted local-mean smoothing-a non-parametric approach - to describe the relationship between state aid and the cost-capacity gap, a positive relationship between the two appears to exist mostly for districts with positive cost-capacity gaps. The smoothing line is essentially flat for districts with negative cost-capacity gaps, suggesting that cost-capacity gaps are irrelevant for the aid distributions among these districts.

More importantly, Figure 3 shows that state education aid has not fully addressed the inequity and inadequacy in Connecticut's school finance. More than 61 percent of school districts in FY2019 are on the right side of the 45-degree line, which means that these districts received less aid than they needed to close the cost-capacity gaps and reach the common student performance target. On the other hand, about 40 percent of districts - those on the left side of the 45-degree line-received more aid than they needed to close the cost-capacity gaps. In addition, districts with similar cost-capacity gaps often received different amounts of state education aid per pupil, with large differences in some cases.

Another way to evaluate state aid distribution is to directly examine the post-aid gap, which is calculated as the cost-capacity gap minus state education aid. If state aid fully addresses finance inequity and inadequacy as defined by this paper, the post-aid gap would be zero for every school district. Otherwise, the post-aid gap would be positive for districts receiving less aid than they need and negative for districts receiving more aid than they need.

state aid per pupil; however, the relationship is not as strong as the one between state education aid and the predicted cost. The enrollment-weighted correlation between state education aid and revenue capacity is -0.58 and significant at the 1 percent level. In addition, as the Kernel-weighted local-mean smoothing line in Appendix Figure 2 suggests, the distribution of state education aid bears no relationship with revenue capacity among school districts with a revenue capacity greater than $\$ 25,000$ per pupil. 
Figure 4 shows the density distributions of the pre-aid gap and the post-aid gap. In comparison, the post-aid gap has a narrower distribution and a shorter right tail, thanks to the equalizing effect of state education aid. ${ }^{31}$ However, a large portion of the post-aid gap distribution is still in the positive area, with a long left tail in the negative area. This suggests that significant inequity and inadequacy in school finance remains even after taking state aid into account.

Table 5 shows that the districts with the largest enrollments, highest child poverty rates, least property wealth, or largest pre-aid gaps tend to have the largest post-aid gaps. While these districts, on average, receive the largest amounts of state education aid per pupil, the aid amounts are not sufficiently large to compensate for their pre-aid gaps, which are significantly bigger than the pre-aid gaps for districts in other quintiles.

\section{Implementing a Gap-based Aid Formula with Political Considerations}

As equation (11) suggests, a modified gap-based aid formula can help Connecticut and other states to approach the equity and adequacy goals with enhanced political feasibility. In the following policy simulations, I present five variations of the gap-based formula that use different tools to incorporate political considerations and thus have different implications for equity, adequacy, and state financial responsibility. ${ }^{32}$

The first formula does not consider political feasibility and simply distributes state aid to each district in the amount equal to the district's cost-capacity gap. As a result, districts with negative cost-capacity gaps receive negative amounts of state aid, meaning they would have to

\footnotetext{
${ }^{31}$ Based on several dispersion measures, Appendix Table 1 shows that the post-aid gap is distributed more evenly than the pre-aid gap.

${ }^{32}$ There certainly can be more variations of the gap-based formula than the five presented in this paper. For example, another variation can include both the (full or partial) hold-harmless provision and the maximum aid.
} 
send money to the state. To avoid that scenario, the second formula gives zero aid to each negativegap district.

The third formula includes a minimum level of aid that is set as a positive, fixed dollar amount per pupil. ${ }^{33}$ For the purpose of illustration, I set this minimum aid as $\$ 55$ per pupil, which is about a third of the lowest amount of state education aid per pupil among Connecticut school districts in FY2019. The fourth formula includes the full hold-harmless provision requiring that no district receive less aid than it actually received in FY2019.

The fifth formula includes both the minimum and maximum levels of aid, which are set as fixed dollar amounts per pupil. ${ }^{34}$ I set the minimum aid to be the same as that in the third formula (that is, $\$ 55$ per pupil) so that the two formulas are comparable. For the purpose of illustration, I set the maximum aid as $\$ 15,000$ per pupil. This cap would be binding for the six school districts that have cost-capacity gaps larger than $\$ 15,000$ per pupil in FY2019.

Figure 5 (divided into parts 1 and 2 for ease of demonstration) shows the simulated distributions of state education aid in FY2019 under these five variations of the gap-based formula. It also includes the existing state aid distribution in that year as a comparison. Under the first formula, with negative aid for negative-gap districts, all school districts would be lined up on the 45-degree line, because the aid amounts that they receive are equal to their cost-capacity gaps. When the aid floors - zero aid, a positive minimum aid, and existing aid held harmless - are installed in the other formulas, districts on the left tail of the gap distribution-mostly those with negative gaps - would deviate upward and away from the 45-degree line. The higher the aid floor

\footnotetext{
${ }^{33}$ Alternatively, the minimum aid can be set as a fixed percentage of the predicted cost. Doing so guarantees that state education aid would fund at least a given percentage of the education cost of each school district.

${ }^{34}$ Alternatively, the maximum aid can be set as a fixed percentage of the predicted cost.
} 
is, the farther these districts would move up and away. On the other hand, when the maximum aid is introduced, districts on the right tail of the gap distribution would deviate downward and away from the 45-degree line. The lower the maximum aid is, the farther these districts would move down and away. By design, the majority of positive-gap districts are not affected by these politically motivated tools and remain on the 45 -degree line.

Table 6 compares disparities in the post-aid gap under the existing aid distribution and different variations of the gap-based formula. The post-aid gaps under the gap-based formulas all show degrees of dispersion that are smaller than that of the post-aid gap under the existing aid distribution. This suggests that implementing a gap-based formula, even one that includes policy tools to increase the formula's political appeal, can significantly improve the equity in school finance. However, only the first gap-based formula (with negative aid for negative-gap districts) completely eliminates the inequity, as the post-aid gap under this formula is zero for each and every district. In comparison, including policy tools such as minimum and maximum levels of aid and a hold-harmless provision results in preserving some inequity.

Policymakers also face tradeoffs between political feasibility and state financial requirements. Table 7 shows that in FY2019 the state would need to increase the aid pool by only 4.56 percent to fund a gap-based formula that included negative aid for negative-gap districts. In this case, additional aid is needed largely because the student test performance levels in many school districts are lower than the target assumed in this simulation exercise. A much larger aid pool would be required if the state installs an aid floor-zero aid, a minimum amount of aid, or the existing amount of aid held harmless. ${ }^{35}$ The required increase in the aid pool relative to the

\footnotetext{
${ }^{35}$ If the state simply redistributes existing aid through a gap-based formula with negative aid for negative-gap districts, state aid would close 95.7 percent of the statewide cost-capacity gaps in FY2019. Alternatively, if the state
} 
existing aid ranges from 37.34 percent under the formula with a zero aid floor (the second formula) to 44.40 percent under the formula with a full hold-harmless provision (the fourth formula).

However, introducing the maximum aid would help to reduce the aid pool requirement. For example, the required increase in the aid pool relative to the existing aid drops from 37.76 percent under the third formula to 28.63 percent under the fifth formula, and the only difference between the two formulas is that the latter includes a maximum amount of aid. In this case, even though the maximum aid is binding for only six school districts, these districts have extraordinarily large cost-capacity gaps and also have large enrollments; therefore, they would lose significant amounts of state aid under the constraints of the maximum aid provision.

Policymakers may want to know which type of school districts would be the "winners" and which type would be the "losers" if the state switches to a gap-based aid formula. ${ }^{36}$ Winners and losers are defined as the ones that would receive more and less aid, respectively, under the new formula compared to what they receive under the existing formula. Table 8 shows that without the hold-harmless protection, school districts with the most property wealth per pupil (that is, in the fifth quintile of property wealth) or with the smallest gaps (that is, in the first quintile of the costcapacity gaps), on average, would receive less aid under the gap-based formulas compared with what they actually received in FY2019. Therefore, these districts would be considered the losers. However, if the hold-harmless provision were put in place, there would be no losers in the absolute sense.

redistributes existing aid through a gap-based formula with zero aid for negative-gap districts, state aid would close 72.8 percent of the cost-capacity gaps among the positive-gap districts.

${ }^{36}$ Appendix Table 2 shows the post-aid gap per pupil by district characteristics (enrollment size, school-age child poverty rate, property wealth per pupil, and the cost-capacity gap per pupil). 
On the other hand, when there is no maximum aid, school districts with the largest enrollments, the highest school-age child poverty rates, the lowest property wealth per pupil, or the largest cost-capacity gaps per pupil, on average, often see the largest percentage increases in state aid under the gap-based formulas. However, when a maximum amount of aid is imposed, these districts may no longer be the biggest winners, because aid distributions for some of them would be constrained by the cap.

\section{Conclusion}

This paper calculates the cost-capacity gap for each Connecticut school district and uses it as a summary measure of the inequity and inadequacy in the state's education finance. Education cost is estimated based on the cost factors identified from a cost function regression, with an assumed common student test performance target and district efficiency level. Revenue capacity is estimated based on taxable property wealth under the representative-tax-system approach. The paper shows that Connecticut school districts have a wide range of cost-capacity gaps and therefore have different needs for state education aid.

This paper uses the cost-capacity gap as a basis for assessing the existing distribution of Connecticut's education aid. It finds that larger-gap districts, on average, received more state aid per pupil than smaller-gap districts. However, many districts - especially large-gap onesreceived less aid than they needed to achieve the assumed common student performance target. Meanwhile, negative-gap and some small-gap districts received more aid than they needed to achieve the common target. Therefore, even after state education aid is taken into account, significant inequity and inadequacy remain in Connecticut's education finance system. 
This paper proposes a gap-based formula to improve the distribution of state education aid. Using this formula as opposed to the existing formula, the state can target education aid more effectively to school districts with greater need for financial assistance. This paper presents policymakers with a menu of policy tools that can enhance the political feasibility of the gap-based formula. These tools include an aid floor and ceiling and a hold-harmless provision. owever, applying these tools would compromise the ability of state aid to eliminate the inequity and inadequacy and require a larger state aid pool than would otherwise be necessary. Facing the tradeoffs, policymakers should carefully consider which tools to use and how to use them to meet their objectives, subject to their financial and political constraints. Finally, the research method and the formula design presented in this paper are flexible and can be adapted easily and applied to other states. 
Appendix. The Statutory ECS Formulas from FY2008 to FY2017

The General Assembly of Connecticut implemented a new ECS formula in FY2008, following then-Governor Rell's proposal based on recommendations from the Commission of Education Finance. While the formula retained the structure presented in equation (1), each of its components was redefined as follows:

- foundation $_{t}=\$ 9,687$ per pupil;

- $(\text { total need students })_{i t}=$ enrollment $_{i t}+33 \% \times{\text { Title } 1 \text { poverty }_{\text {count }}+}_{i t}+$ $15 \% \times$ students with limited English proficiency $y_{i t}$

- $\quad(\text { base aid ratio })_{i t}=1-\frac{{\text { town } \text { wealth }_{i t}}_{1.75 \times \text { median }\left(\text { town }_{\text {wealth }} \text { it }\right)}}{\text {, where }}$ town wealth $h_{i t}=\frac{1}{2} \times$ $\left(\frac{\text { adjusted } E N G L_{i t}}{\text { total need students }}+\frac{\text { adjusted } E N G L_{i t}}{\text { total population }_{i t}}\right) \quad$ in $\quad$ which $\quad$ adjusted $E N G L_{i t}=\left[\frac{1}{2} \times\right.$

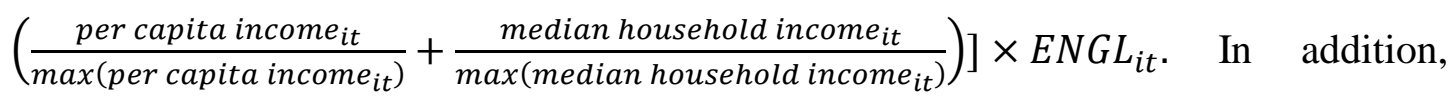
there is a minimum base aid ratio of 13 percent for 20 cities and towns with the highest percentage of children aged 5 through 17 living in poverty and 9 percent for all other cities and towns.

The General Assembly of Connecticut changed the ECS formula again in 2013, following the recommendations of the ECS Task Force. Without changing the basic structure of the formula, it redefined each component of the formula as follows:

- foundation $_{t}=\$ 11,525$ per pupil;

- $\quad(\text { total need students })_{i t}=$ enrollment $_{i t}+30 \% \times$ students eligible for free or reduced-priced meals or free milk it $_{\text {; }}$; 


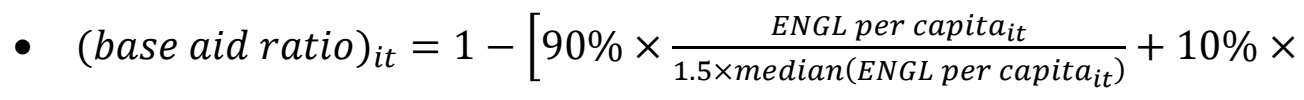

$\left.\frac{\text { median household } \text { income }_{i t}}{1.5 \times \text { median }\left(\text { median household } \text { income }_{i t}\right)}\right]$. In addition, there is a minimum base aid ratio of 10 percent for 30 cities and towns classified as Alliance Districts and 2 percent for all other cities and towns. 


\section{References}

Advisory Commission on Intergovernmental Relations. 1962. "Measures of State and Local Fiscal Capacity and Tax Effort." Washington, D.C: Government Printing Office.

Baker, Bruce, Mark Weber, Ajay Srikanth, Robert Kim, and Michael Atzbi. 2018. "The Real Shame of the Nation: The Causes and Consequences of Interstate Inequity in Public School Investments." Policy Report. Newark, NJ: Education Law Center of New Jersey \& Rutgers Graduate School of Education.

Connecticut School Finance Project. 2018. "FY 2019 Budget Changes to School Finance." Presentation updated June 1, 2018. New Haven, CT: Connecticut School Finance Project.

Connecticut School Finance Project. 2019. "School Finance 101: An Introduction to How Public Schools Are Funded in Connecticut." Presentation updated March 21, 2019. New Haven, CT: Connecticut School Finance Project.

Downes, Thomas, and Thomas Pogue. 1992. "Intergovernmental Aid to Reduce Fiscal Disparities: Problems of Definition and Measurement." Public Finance Quaterly 20(4): 468482.

Downes, Thomas, and Thomas Pogue. 1994. "Adjusting School Aid Formulas for the Higher Cost of Educating Disadvantaged Students." National Tax Journal 47(1): 89-110.

Duncombe, William. 2002. "Estimating the Cost of an Adequate Education in New York." Working Paper 44. Syracuse, NY: Syracuse University, Center for Policy Research.

Duncombe, William. 2006. "Responding to the Charge of Alchemy: Strategies for Evaluating the Reliability and Validity of Costing-out Research." Journal of Education Finance 32(2): 137-169.

Duncombe, William. 2007. "Estimating the Cost of Meeting Student Performance Standards in the St. Louis Public Schools." Report Prepared for the St. Louis Board of Education. Syracuse, NY: Syracuse University, Center for Policy Research.

Duncombe, William, Anna Lukemeyer, and John Yinger. 2003. "Financing an Adequate Education: A Case Study of New York." In Developments in School Finance 2001-2002, 129-153. Washington, DC: U.S. Department of Education.

Duncombe, William, John Ruggiero, and John Yinger. 1996. "Alternative Approaches to Measuring the Cost of Education." In Holding Schools Accountable: Performance-Based Reform in Education, ed. H.F. Ladd, 327-356, Washington, DC: Brookings Institution.

Duncombe, William, and John Yinger. 1997. "Why Is It So Hard to Help Central City Schools?" Journal of Policy Analysis and Management 16(1): 85-113.

Duncombe, William, and John Yinger. 1998. "School Finance Reform: Aid Formulas and Equity Objectives." National Tax Journal 51(2): 239-262. 
Duncombe, William, and John Yinger. 1999. "Performance Standards and Education Cost Indexes: You Can't Have One without the Other." In Equity and Adequacy in Education Finance: Issues and Perspectives, ed. Helen F. Ladd, Rosemary Chalk, and Janet S. Hansen, 260-297, Washington, DC: National Academies Press.

Duncombe, William, and John Yinger. 2000. "Financing Higher Student Performance Standards: The Case of New York State." Economics of Education Review 19(4): 363-386.

Duncombe, William, and John Yinger. 2005a. "Estimating the Costs of Meeting Student Performance Outcomes Adopted by the Kansas State Board of Education." Report Prepared for the Kansas Legislative Division of Post Audit. Syracuse, NY: Syracuse University, Center for Policy Research.

Duncombe, William, and John Yinger. 2005b. "How Much More Does a Disadvantaged Student Cost?" Economics of Education Review 24(5): 513-532.

Duncombe, William, and John Yinger. 2006. "Understanding the Incentives in California's Education Finance System." Report Prepared for the Getting Down to Facts Project. Syracuse, NY: Syracuse University, Center for Policy Research.

Duncombe, William, and John Yinger. 2007. "Does School District Consolidation Cut Costs?" Education Finance and Policy 2(4): 341-375.

Duncombe, William, and John Yinger. 2011a. "Are Education Cost Functions Ready for Prime Time? An Examination of Their Validity and Reliability." Peabody Journal of Education 86(1): 28-57.

Duncombe, William, and John Yinger. 2011b. "Making Do: State Constraints and Local Responses in California's Education Finance System." International Tax and Public Finance 18(3): 337-368.

Gronberg, Timothy J., Dennis W. Jansen, and Lori L. Taylor. 2011. "The Adequacy of Educational Cost Functions: Lessons from Texas." Peabody Journal of Education 86(1): $3-27$.

Gronberg, Timothy J., Dennis W. Jansen, Lori L. Taylor, and Kevin Booker. 2004. "School Outcomes and School Costs: The Cost Function Approach." Draft Paper. College Station, TX: Texas A\&M University.

Guzman, Gloria G. 2018. "Household Income: 2018." American Community Survey Brief 18-01. Washington, DC: U.S. Census Bureau.

Imazeki, Jennifer. 2001. "Grade-dependent Costs of Education: Evidence from Illinois." Draft Paper. San Diego, CA: San Diego State University.

Imazeki, Jennifer. 2008. "Assessing the Costs of Adequacy in California Public Schools: A Cost Function Approach." Education Finance and Policy 3(1): 90-108. 
Imazeki, Jennifer, and Andrew Reschovsky. 2003. "Financing Adequate Education in Rural Settings." Journal of Education Finance 29(2): 137-156.

Imazeki, Jennifer, and Andrew Reschovsky. 2004. "Is No Child Left Behind an Un (or Under) funded Federal Mandate? Evidence from Texas." National Tax Journal 57(3): 571-588.

Imazeki, Jennifer, and Andrew Reschovsky. 2005. "Assessing the Use of Econometric Analysis in Estimating the Costs of Meeting State Education Accountability Standards: Lessons from Texas." Peabody Journal of Education 80(3): 96-125.

Imazeki, Jennifer, and Andrew Reschovsky. 2006. "Does No Child Left Behind Place a Fiscal Burden on States? Evidence from Texas." Education Finance and Policy 1(2): 217-246.

Ladd, Helen F. 1994. "Measuring Disparities in the Fiscal Condition of Local Governments." In Fiscal Equalization for State and Local Government Finance, ed. John E. Anderson, 21-53, Westport, CT: Praeger Publishers.

Ladd, Helen F., Andrew Reschovsky, and John Yinger. 1991. "Measuring the Fiscal Condition of Cities in Minnesota." Saint Paul, MN: Legislative Commission on Planning and Fiscal Policy.

Ladd, Helen F., and John Yinger. 1989. America's Ailing Cities: Fiscal Health and the Design of Urban Policy." Baltimore, MD: John Hopkins University Press.

Reschovsky, Andrew, and Jennifer Imazeki. 2003. "Let No Child Be Left Behind: Determining the Cost of Improving Student Performance." Public Finance Review 31(3): 263-290.

Zhao, Bo. 2018. "From Urban Core to Wealthy Towns: Nonschool Fiscal Disparities across Municipalities." Public Finance Review 46(3): 421-453.

Zhao, Bo. 2020. "Estimating the Cost Function of Connecticut Public K-12 Education: Implications for Inequity and Inadequacy in School Spending." Research Department Working Papers. Boston, MA: Federal Reserve Bank of Boston. 
Table 1. Results of the Cost Regression

Connecticut K-12 School Districts, 2009-2013

\begin{tabular}{|c|c|c|}
\hline & \multicolumn{2}{|l|}{ Dependent Variables } \\
\hline & $\begin{array}{c}\text { Percentage of Students Reaching or Exceeding } \\
\text { Proficiency in Math, Reading, and Writing } \\
\text { (First Stage) }\end{array}$ & $\begin{array}{l}\text { Log of Current } \\
\text { Spending per Pupi } \\
\text { (Second Stage) }\end{array}$ \\
\hline \multicolumn{3}{|l|}{ Instrumental Variables: } \\
\hline Neighbor Districts' Percentage of Property Tax Base from Businesses & $\begin{array}{l}-1.093^{* * *} \\
(0.353)\end{array}$ & \\
\hline Neighbor Districts' Percentage of Adults without a High School Degree & $\begin{array}{c}0.888^{*} \\
(0.520)\end{array}$ & \\
\hline \multicolumn{3}{|l|}{ Education Outcome: } \\
\hline Percentage of Students Reaching or Exceeding Proficiency in Math, Reading, and Writing & & $\begin{array}{c}0.010^{*} \\
(0.005)\end{array}$ \\
\hline \multicolumn{3}{|l|}{ Cost Factors: } \\
\hline Percentage of School-age Children (Aged 5-17) from Families Living in Poverty & $\begin{array}{c}-0.734^{* * *} \\
(0.156)\end{array}$ & $\begin{array}{l}0.012^{* *} \\
(0.005)\end{array}$ \\
\hline Percentage of Children Enrolled in Public Schools Living in Single-parent or Non-family Households & $\begin{array}{c}-0.122^{* * *} \\
(0.038)\end{array}$ & $\begin{array}{c}0.003^{*} \\
(0.002)\end{array}$ \\
\hline Dummy for Enrollment $<2,000$ & $\begin{array}{c}-0.962 \\
(0.694)\end{array}$ & $\begin{array}{l}0.072^{* * *} \\
(0.022)\end{array}$ \\
\hline Dummy for Regional School District & $\begin{array}{c}-0.480 \\
(0.466)\end{array}$ & $\begin{array}{l}0.077^{* * *} \\
(0.019)\end{array}$ \\
\hline \multicolumn{3}{|l|}{ Efficiency Variables: } \\
\hline Log of Real ENGL per Pupil & $\begin{array}{c}-0.136 \\
(1.021)\end{array}$ & $\begin{array}{l}0.221^{* * *} \\
(0.025)\end{array}$ \\
\hline Log of Real Median Household Income & $\begin{array}{c}-2.705 \\
(2.792)\end{array}$ & $\begin{array}{r}-0.027 \\
(0.109)\end{array}$ \\
\hline Percentage of Total Revenue from Federal and State Sources & $\begin{array}{r}-0.065^{*} \\
(0.035)\end{array}$ & $\begin{array}{l}0.003^{* * *} \\
(0.001)\end{array}$ \\
\hline Percentage of Property Tax Base from Businesses & $\begin{array}{c}-0.047 \\
(0.075)\end{array}$ & $\begin{array}{l}0.004^{* * *} \\
(0.001)\end{array}$ \\
\hline Percentage of Registered Republican Voters & $\begin{array}{l}0.198^{* * *} \\
(0.053)\end{array}$ & $\begin{array}{c}-0.006^{* * *} \\
(0.002)\end{array}$ \\
\hline Percentage of Population Aged 65 and Older & $\begin{array}{c}-0.028 \\
(0.098)\end{array}$ & $\begin{array}{c}-0.003 \\
(0.003)\end{array}$ \\
\hline Percentage of Adults with a Bachelor's Degree or Higher & $\begin{array}{c}0.068 \\
(0.046)\end{array}$ & $\begin{array}{l}0.004^{* * *} \\
(0.001)\end{array}$ \\
\hline Percentage of Owner-occupied Housing Units & $\begin{array}{c}0.057 \\
(0.055)\end{array}$ & $\begin{array}{c}0.003 \\
(0.002)\end{array}$ \\
\hline Dummy for Bordering Massachusetts & $\begin{array}{c}1.740 \\
(1.362)\end{array}$ & $\begin{array}{c}-0.017 \\
(0.022)\end{array}$ \\
\hline Dummy for Bordering New York & $\begin{array}{c}-2.214^{* * *} \\
(0.761)\end{array}$ & $\begin{array}{c}0.021 \\
(0.039)\end{array}$ \\
\hline Dummy for Bordering Rhode Island & $\begin{array}{c}-0.240 \\
(1.624)\end{array}$ & $\begin{array}{r}-0.078^{*} \\
(0.042)\end{array}$ \\
\hline Constant & $\begin{array}{l}109.796^{* * *} \\
(13.016)\end{array}$ & $\begin{array}{c}-0.123 \\
(0.730)\end{array}$ \\
\hline Observations & 585 & 585 \\
\hline Endogeneity Test P-value & & 0.052 \\
\hline Kleibergen-Paap Underidentification Test P-value & & 0.017 \\
\hline Hansen J Overidentification Test P-value & & 0.218 \\
\hline Adjusted R-squared & 0.908 & 0.574 \\
\hline
\end{tabular}

Source: Zhao (2020)

Notes: All regressions include year and labor market area (LMA) fixed effects. Standard errors are clustered at the school district level.

${ }^{*} p<0.10,{ }^{* *} p<0.05,{ }^{* * *} p<0.01$ 
Table 2. Comparing Disparities between Two Measures of Property Tax Capacity FY2019

\begin{tabular}{lcr}
\hline & \multicolumn{1}{c}{$\begin{array}{c}\text { Property Tax Capacity Calculated } \\
\text { Using the Representative-tax-system Approach }\end{array}$} & $\begin{array}{c}\text { Propterty Tax Capacity Calculated } \\
\text { Using the Income-with-tax-exporting Approach }\end{array}$ \\
\hline $\begin{array}{l}\text { Range } \\
\text { (Thousands of 2019 Dollars) }\end{array}$ & 49.55 & 18.30 \\
$\frac{\text { Maximum }}{\text { Minimum }}$ & 17.19 & 4.64 \\
$\frac{90^{t h} \text { Percentile }}{10^{t h} \text { Percentile }}$ & 4.99 & 2.50 \\
$\frac{80^{t h} \text { Percentile }}{20^{t h} \text { Percentile }}$ & 2.64 & 1.85 \\
Gini Coefficient & 0.33 & 0.18 \\
Coefficient of Variation & 0.76 & 0.33 \\
\hline
\end{tabular}

Source: Author's calculations

Notes: The sample includes 119 Connecticut K-12 school districts. Property tax revenue raised under the standard tax rate or the standard tax burden is assumed to be able to fund 55 percent of the statewide predicted cost. The student test performance target for each school district is assumed to be 61.5 percent of students meeting or exceeding the achievement standard. The FY2019 enrollment of each district is used as the weight to calculate the disparity measures. 
Table 3. Comparing Disparities in Predicted Cost with Disparities in Revenue Capacity FY2019

\begin{tabular}{lcc}
\hline & Predicted Cost per Pupil & Revenue Capacity per Pupil \\
\hline $\begin{array}{l}\text { Range } \\
\text { (Thousands of 2019 Dollars) }\end{array}$ & 13.45 & 49.82 \\
$\frac{\text { Maximum }}{\text { Minimum }}$ & 1.91 & 8.61 \\
$\begin{array}{l}\frac{90^{t h} \text { Percentile }}{10^{t h} \text { Percentile }} \\
\frac{80^{t h} \text { Percentile }}{20^{t h} \text { Percentile }}\end{array}$ & 1.61 & 2.46 \\
Gini Coefficient & 1.36 & 1.88 \\
Coefficient of Variation & 0.10 & 0.24 \\
\hline
\end{tabular}

Source: Author's calculations

Notes: The sample includes 119 Connecticut K-12 school districts. Property taxes are assumed to fund 55 percent of the statewide predicted cost. The student test performance target for each school district is assumed to be 61.5 percent of students meeting or exceeding the achievement standard. The FY2019 enrollment of each district is used as the weight to calculate the disparity measures. 
Table 4. Cost-capacity Gap by District Characteristics FY2019, Thousands of 2019 Dollars

\begin{tabular}{cccc}
\hline & $\begin{array}{c}\text { Cost-capacity Gap } \\
\text { per Pupil }\end{array}$ & $\begin{array}{c}\text { Predicted Cost } \\
\text { per Pupil }\end{array}$ & $\begin{array}{c}\text { Revenue Capacity } \\
\text { per Pupil }\end{array}$ \\
\hline Enrollment Quintiles & & & \\
1 & 2.59 & 18.16 & 15.57 \\
2 & 4.72 & 17.03 & 12.31 \\
3 & 3.72 & 17.12 & 13.40 \\
4 & 1.23 & 16.52 & 15.28 \\
5 & 7.58 & 20.47 & 12.89 \\
\hline School-age-child-poverty Quintiles & & & \\
1 & 0.68 & 15.75 & 15.07 \\
2 & 0.94 & 16.25 & 19.31 \\
3 & -2.79 & 16.37 & 12.63 \\
4 & 5.04 & 17.68 & 10.28 \\
5 & 11.86 & 22.14 & \\
1 & & & 8.16 \\
2 & 14.49 & 22.65 & 11.15 \\
3 & 6.13 & 17.28 & 12.20 \\
4 & 4.61 & 16.81 & 24.43 \\
5 & 2.09 & 16.52 & \\
\hline Property Wealth Quintiles & -7.80 & 16.63 & \\
\hline
\end{tabular}

Source: Author's calculations

Notes: The sample includes 119 Connecticut K-12 school districts. Property taxes are assumed to fund 55 percent of the statewide predicted cost. The student test performance target for each school district is assumed to be 61.5 percent of students meeting or exceeding the achievement standard. The FY2019 enrollment of each district is used as the weight to calculate the weighted average values for each quintile. Property wealth per pupil is measured as Equalized Net Grand List (ENGL) per pupil. The FY2019 school-age-child-poverty quintiles are assumed to be the same as the FY2013 school-age-child-poverty quintiles. Quintiles are ranked from low to high. 
Table 5. Post-aid Gap by District Characteristics

FY2019, Thousands of 2019 Dollars

\begin{tabular}{|c|c|c|c|}
\hline & Post-aid Gap per Pupil & Cost-capacity Gap per Pupil & Existing State Aid per Pupil \\
\hline \multicolumn{4}{|c|}{ Enrollment Quintiles } \\
\hline 1 & -1.71 & 2.59 & 4.30 \\
\hline 2 & 0.34 & 4.72 & 4.39 \\
\hline 3 & 0.13 & 3.72 & 3.59 \\
\hline 4 & -1.69 & 1.23 & 2.92 \\
\hline 5 & 1.30 & 7.58 & 6.28 \\
\hline \multicolumn{4}{|c|}{ School-age-child-poverty Quintiles } \\
\hline 1 & -0.73 & 0.68 & 1.41 \\
\hline 2 & -1.19 & 0.94 & 2.12 \\
\hline 3 & -5.61 & -2.79 & 2.81 \\
\hline 4 & 0.32 & 5.04 & 4.73 \\
\hline 5 & 3.57 & 11.86 & 8.29 \\
\hline \multicolumn{4}{|c|}{ Property Wealth Quintiles } \\
\hline 1 & 4.94 & 14.49 & 9.55 \\
\hline 2 & 1.35 & 6.13 & 4.78 \\
\hline 3 & 1.65 & 4.61 & 2.96 \\
\hline 4 & -0.33 & 2.09 & 2.42 \\
\hline 5 & -8.91 & -7.80 & 1.11 \\
\hline \multicolumn{4}{|c|}{ Cost-capacity Gap Quintiles } \\
\hline 1 & -8.57 & -7.48 & 1.08 \\
\hline 2 & 0.10 & 2.36 & 2.26 \\
\hline 3 & 1.37 & 4.39 & 3.02 \\
\hline 4 & 1.53 & 6.17 & 4.64 \\
\hline 5 & 4.91 & 14.50 & 9.59 \\
\hline
\end{tabular}

Source: Author's calculations

Notes: The sample includes 119 Connecticut K-12 school districts. The post-aid gap per pupil is defined as cost-capacity gap per pupil minus state aid per pupil. Property taxes are assumed to fund 55 percent of the statewide predicted cost. The student test performance target for each school district is assumed to be 61.5 percent of students meeting or exceeding the achievement standard. The FY2019 enrollment of each district is used as the weight to calculate the weighted average values for each quintile. Property wealth per pupil is measured as Equalized Net Grand List (ENGL) per pupil. The FY2019 school-age-child-poverty quintiles are assumed to be the same as the FY2013 school-age-child-poverty quintiles. Quintiles are ranked from low to high. 
Table 6. Comparing Disparities in Post-aid Gap per Pupil under Different Scenarios of State Aid Distribution FY2019, Thousands of 2019 Dollars

\begin{tabular}{|c|c|c|c|c|c|c|}
\hline & \multirow[b]{2}{*}{$\begin{array}{c}\text { Post-aid } \\
\text { Gap after } \\
\text { Existing } \\
\text { State Aid }\end{array}$} & \multicolumn{5}{|c|}{ Post-aid Gap after State Aid Distributed by a Gap-based Formula with: } \\
\hline & & $\begin{array}{l}\text { Negative Aid to } \\
\text { Negative-gap } \\
\text { Districts } \\
\text { (1) }\end{array}$ & $\begin{array}{c}\text { Zero Aid to } \\
\text { Negative-gap } \\
\text { Districts } \\
(2)\end{array}$ & $\begin{array}{l}\text { Minimum } \\
\text { Aid } \\
\text { (3) }\end{array}$ & $\begin{array}{c}\text { Holding } \\
\text { Existing Aid } \\
\text { Harmless } \\
(4)\end{array}$ & $\begin{array}{c}\text { Minimum } \\
\text { and Maximum } \\
\text { Aid } \\
(5)\end{array}$ \\
\hline Range & 49.28 & 0.00 & 40.45 & 40.51 & 40.65 & 46.21 \\
\hline $90^{t h}$ Percentile $-10^{t h}$ Percentile & 10.58 & 0.00 & 2.80 & 2.86 & 4.69 & 3.92 \\
\hline $80^{t h}$ Percentile $-20^{t h}$ Percentile & 6.57 & 0.00 & 0.00 & 0.00 & 1.97 & 0.00 \\
\hline $75^{\text {th }}$ Percentile $-25^{\text {th }}$ Percentile & 4.70 & 0.00 & 0.00 & 0.00 & 1.32 & 0.00 \\
\hline Standard Deviation & 7.20 & 0.00 & 6.05 & 6.06 & 6.13 & 6.31 \\
\hline
\end{tabular}

Source: Author's calculations

Notes: The sample includes 119 Connecticut K-12 school districts. The post-aid gap per pupil is defined as cost-capacity gap per pupil minus state aid per pupil. Property taxes are assumed to fund 55 percent of the statewide predicted cost. The student test performance target for each school district is assumed to be 61.5 percent of students meeting or exceeding the achievement standard. In Scenario (3), the minimum aid is set as $\$ 55$ per pupil. In Scenario (5), the minimum aid and maximum aid are set as $\$ 55$ per pupil and $\$ 15,000$ per pupil, respectively. 
Table 7. State Aid Pool Required under Different Distribution Scenarios

FY2019

\begin{tabular}{|c|c|c|c|c|c|c|}
\hline & \multirow{2}{*}{$\begin{array}{c}\text { Existing } \\
\text { State } \\
\text { Aid } \\
\text { Distribution }\end{array}$} & \multicolumn{5}{|c|}{ Post-aid Gap after State Aid Distributed by a Gap-based Formula with: } \\
\hline & & $\begin{array}{l}\text { Negative Aid to } \\
\text { Negative-gap } \\
\text { Districts } \\
\text { (1) }\end{array}$ & $\begin{array}{l}\text { Zero Aid to } \\
\text { Negative-gap } \\
\text { Districts } \\
(2)\end{array}$ & $\begin{array}{l}\text { Minimum } \\
\text { Aid } \\
(3)\end{array}$ & $\begin{array}{c}\text { Holding } \\
\text { Existing Aid } \\
\text { Harmless } \\
(4)\end{array}$ & $\begin{array}{c}\text { Minimum } \\
\text { and Maximum } \\
\text { Aid } \\
(5)\end{array}$ \\
\hline $\begin{array}{l}\text { Aid Pool } \\
\text { (Billions of } 2019 \text { Dollars) }\end{array}$ & 2.41 & 2.52 & 3.31 & 3.31 & 3.48 & 3.09 \\
\hline $\begin{array}{l}\text { Additional Aid Required Relative to Existing Aid } \\
\text { (Billions of } 2019 \text { Dollars) }\end{array}$ & 0.00 & 0.11 & 0.90 & 0.91 & 1.07 & 0.69 \\
\hline $\begin{array}{l}\text { Additional Aid Required as a Percentage of Existing Aid } \\
(\%)\end{array}$ & 0.00 & 4.56 & 37.34 & 37.76 & 44.40 & 28.63 \\
\hline
\end{tabular}

Source: Author's calculations

Notes: The sample includes 119 Connecticut K-12 school districts. Property taxes are assumed to fund 55 percent of the statewide predicted cost. The student test performance target for each school district is assumed to be 61.5 percent of students meeting or exceeding the achievement standard. In Scenario (3), the minimum aid is set as $\$ 55$ per pupil. In Scenario (5), the minimum aid and maximum aid are set as $\$ 55$ per pupil and $\$ 15,000$ per pupil, respectively. 
Table 8. State Aid per Pupil by District Characteristics

FY2019, Thousands of 2019 Dollars

\begin{tabular}{|c|c|c|c|c|c|c|}
\hline & $\begin{array}{c}\text { Existing } \\
\text { State } \\
\text { Aid } \\
\text { Distribution }\end{array}$ & \multicolumn{5}{|c|}{ Post-aid Gap after State Aid Distributed by a Gap-based Formula with: } \\
\hline \multicolumn{7}{|c|}{ Enrollment Quintiles } \\
\hline 1 & 4.30 & 2.59 & 4.71 & 4.72 & 5.18 & 4.72 \\
\hline 4 & 2.92 & 1.23 & 3.43 & 3.45 & 3.84 & 3.45 \\
\hline 5 & 6.28 & 7.58 & 9.47 & 9.48 & 9.76 & 8.57 \\
\hline \multicolumn{7}{|c|}{ School-age-child-poverty Quintiles } \\
\hline 1 & 1.41 & 0.68 & 2.57 & 2.59 & 2.70 & 2.59 \\
\hline 2 & 2.12 & 0.94 & 2.29 & 2.31 & 2.64 & 2.31 \\
\hline 1 & 9.55 & 14.49 & 14.49 & 14.49 & 14.49 & 13.09 \\
\hline 2 & 4.78 & 6.13 & 6.13 & 6.13 & 6.19 & 6.13 \\
\hline 3 & 2.96 & 4.61 & 4.61 & 4.61 & 4.67 & 4.61 \\
\hline 4 & 2.42 & 2.09 & 2.15 & 2.15 & 2.85 & 2.15 \\
\hline 5 & 1.11 & -7.80 & 0.04 & 0.09 & 1.11 & 0.09 \\
\hline \multicolumn{7}{|c|}{ Cost-capacity Gap Quintiles } \\
\hline 1 & 1.08 & -7.48 & 0.04 & 0.09 & 1.08 & 0.09 \\
\hline 2 & 2.26 & 2.36 & 2.36 & 2.36 & 2.95 & 2.36 \\
\hline 3 & 3.02 & 4.39 & 4.39 & 4.39 & 4.44 & 4.39 \\
\hline 4 & 4.64 & 6.17 & 6.17 & 6.17 & 6.26 & 6.17 \\
\hline 5 & 9.59 & 14.50 & 14.50 & 14.50 & 14.50 & 13.12 \\
\hline
\end{tabular}

Source: Author's calculations

Notes: The sample includes 119 Connecticut K-12 school districts. Property taxes are assumed to fund 55 percent of the statewide predicted cost. The student test performance target for each school district is assumed to be 61.5 percent of students meeting or exceeding the achievement standard. The FY2019 enrollment of each district is used as the weight to calculate the weighted average values for each quintile. Property wealth per pupil is measured as Equalized Net Grand List (ENGL) per pupil. The FY2019 school-age-child-poverty quintiles are assumed to be the same as the FY2013 school-age-child-poverty quintiles. Quintiles are ranked from low to high. In Scenario (3), the minimum aid is set as $\$ 55$ per pupil. In Scenario (5), the minimum aid and maximum aid are set as $\$ 55$ per pupil and $\$ 15,000$ per pupil, respectively. 
Appendix Table 1. Comparing Disparities in Cost-capacity Gap with Disparities in Post-aid Gap FY2019, Thousands of 2019 Dollars

\begin{tabular}{lcc}
\hline & Cost-capacity Gap per Pupil & Post-aid Gap per Pupil \\
\hline Range & 61.15 & 49.28 \\
$90^{\text {th }}$ Percentile $-10^{\text {th }}$ Percentile & 18.86 & 10.58 \\
$80^{\text {th }}$ Percentile $-20^{\text {th }}$ Percentile & 12.81 & 6.57 \\
$75^{\text {th }}$ Percentile $-25^{\text {th }}$ Percentile & 8.61 & 4.70 \\
Standard Deviation & 9.81 & 7.20 \\
\hline
\end{tabular}

Source: Author's calculations

Notes: The sample includes 119 Connecticut K-12 school districts. The post-aid gap per pupil is defined as the cost-capacity gap per pupil minus state aid per pupil. Property taxes are assumed to fund 55 percent of the statewide predicted cost. The student test performance target for each school district is assumed to be 61.5 percent of students meeting or exceeding the achievement standard. The FY2019 enrollment of each district is used as the weight to calculate the disparity measures. 
Appendix Table 2. Post-aid Gap per Pupil by District Characteristics FY2019, Thousands of 2019 Dollars

\begin{tabular}{|c|c|c|c|c|c|c|}
\hline & \multirow[b]{2}{*}{$\begin{array}{c}\text { Existing } \\
\text { State } \\
\text { Aid } \\
\text { Distribution }\end{array}$} & \multicolumn{5}{|c|}{ Post-aid Gap after State Aid Distributed by a Gap-based Formula with: } \\
\hline & & $\begin{array}{c}\text { Negative Aid to } \\
\text { Negative-gap } \\
\text { Districts } \\
(1)\end{array}$ & $\begin{array}{c}\text { Zero Aid to } \\
\text { Negative-gap } \\
\text { Districts } \\
(2)\end{array}$ & $\begin{array}{c}\text { Minimum } \\
\text { Aid } \\
(3)\end{array}$ & $\begin{array}{c}\text { Holding } \\
\text { Existing Aid } \\
\text { Harmless } \\
(4)\end{array}$ & $\begin{array}{c}\text { Minimum } \\
\text { and Maximum } \\
\text { Aid } \\
(5)\end{array}$ \\
\hline \multicolumn{7}{|c|}{ Enrollment Quintiles } \\
\hline 1 & -1.71 & 0.00 & -2.12 & -2.13 & -2.59 & -2.13 \\
\hline 2 & 0.34 & 0.00 & -0.26 & -0.26 & -0.62 & -0.26 \\
\hline 3 & 0.13 & 0.00 & -0.45 & -0.46 & -0.79 & -0.41 \\
\hline 4 & -1.69 & 0.00 & -2.19 & -2.21 & -2.60 & -2.21 \\
\hline 5 & 1.30 & 0.00 & -1.89 & -1.90 & -2.18 & -0.99 \\
\hline \multicolumn{7}{|c|}{ School-age-child-poverty Quintiles } \\
\hline 1 & -0.73 & 0.00 & -1.89 & -1.91 & -2.02 & -1.91 \\
\hline 2 & -1.19 & 0.00 & -1.35 & -1.37 & -1.70 & -1.37 \\
\hline 3 & -5.61 & 0.00 & -5.71 & -5.73 & -6.21 & -5.73 \\
\hline 4 & 0.32 & 0.00 & -0.22 & -0.23 & -0.64 & -0.23 \\
\hline 5 & 3.57 & 0.00 & -0.30 & -0.30 & -0.64 & 0.86 \\
\hline \multicolumn{7}{|c|}{ Property Wealth Quintiles } \\
\hline 1 & 4.94 & 0.00 & 0.00 & 0.00 & 0.00 & 1.41 \\
\hline 2 & 1.35 & 0.00 & 0.00 & 0.00 & -0.06 & 0.00 \\
\hline 3 & 1.65 & 0.00 & 0.00 & 0.00 & -0.06 & 0.00 \\
\hline 4 & -0.33 & 0.00 & -0.06 & -0.07 & -0.76 & -0.07 \\
\hline 5 & -8.91 & 0.00 & -7.84 & -7.89 & -8.91 & -7.89 \\
\hline \multicolumn{7}{|c|}{ Cost-capacity Gap Quintiles } \\
\hline 1 & -8.57 & 0.00 & -7.52 & -7.57 & -8.57 & -7.57 \\
\hline 2 & 0.10 & 0.00 & 0.00 & 0.00 & -0.59 & 0.00 \\
\hline 3 & 1.37 & 0.00 & 0.00 & 0.00 & -0.05 & 0.00 \\
\hline 4 & 1.53 & 0.00 & 0.00 & 0.00 & -0.09 & 0.00 \\
\hline 5 & 4.91 & 0.00 & 0.00 & 0.00 & 0.00 & 1.38 \\
\hline
\end{tabular}

Source: Author's calculations

Notes: The sample includes 119 Connecticut K-12 school districts. Property taxes are assumed to fund 55 percent of the statewide predicted cost. The student test performance target for each school district is assumed to be 61.5 percent of students meeting or exceeding the achievement standard. The FY2019 enrollment of each district is used as the weight to calculate the weighted average values for each quintile. Property wealth per pupil is measured as Equalized Net Grand List (ENGL) per pupil. The FY2019 school-age-child-poverty quintiles are assumed to be the same as the FY2013 school-age-child-poverty quintiles. Quintiles are ranked from low to high. In Scenario (3), the minimum aid is set as $\$ 55$ per pupil. In Scenario (5), the minimum aid and maximum aid are set as $\$ 55$ per pupil and $\$ 15,000$ per pupil, respectively. 
Figure 1. Comparing Two Measures of Property Tax Capacity

119 Connecticut K-12 School Districts, FY2019

(Thousands of 2019 Dollars per Pupil)

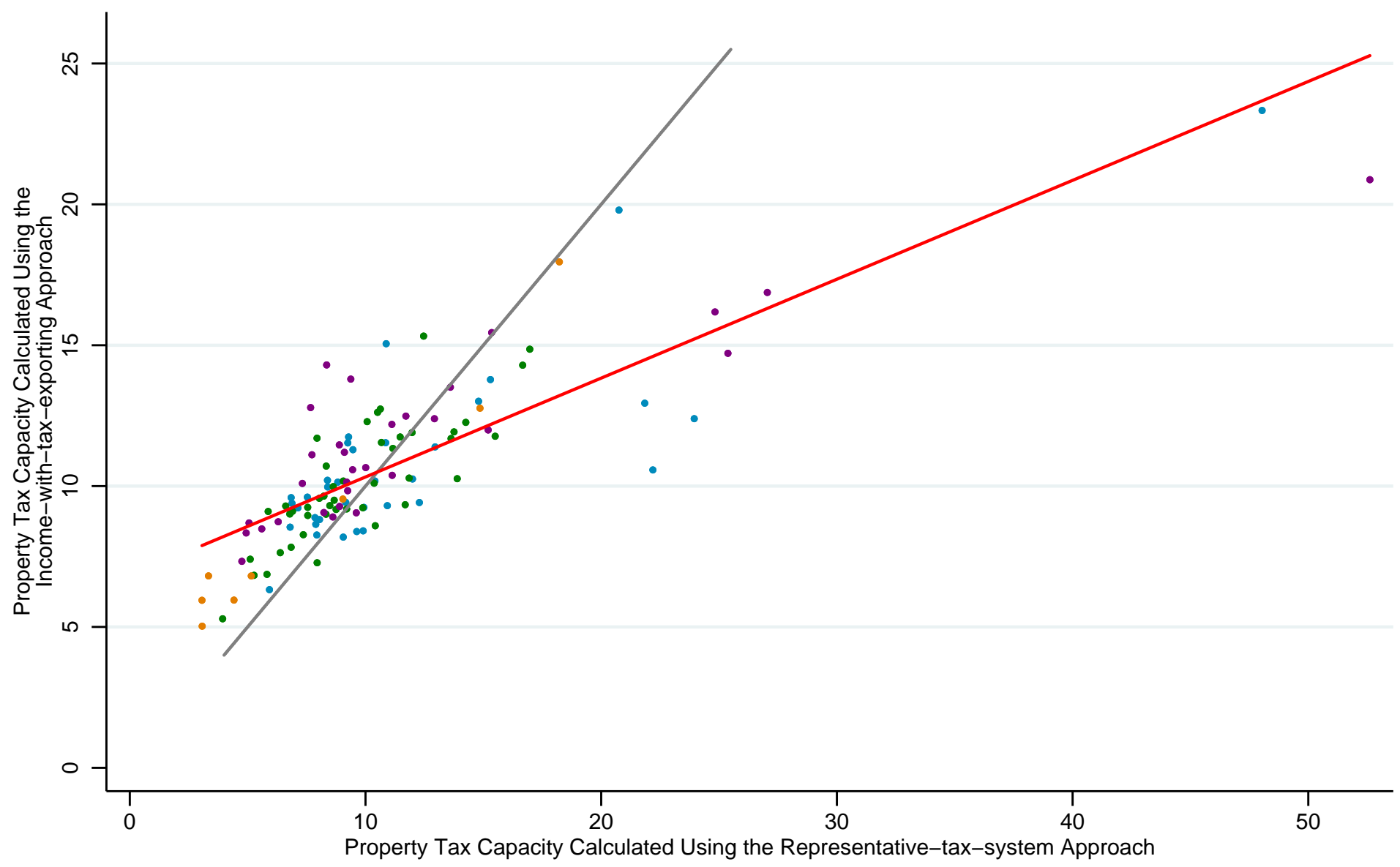

\begin{tabular}{|c|c|c|c|c|}
\hline $\begin{array}{l}\text { - Enrollment } \leq 2,000 \\
\text { - Enrollment }>10,000\end{array}$ & $\bullet$ & $\begin{array}{l}2,000<\text { Enrollment } \leq 4,000 \\
45 \text {-dearee Line }\end{array}$ & • & $4,000<$ Enrollment $\leq 10,000$ \\
\hline
\end{tabular}

Source: Author's calculations

Notes: Property tax revenue raised under the standard tax rate or the standard tax burden is assumed to be able to fund 55 percent of the statewide predicted cost. The student test performance target for each school district is assumed to be 61.5 percent of students meeting or exceeding the achievement standard. The red straight line is generated from a univariate regression that describes a simple linear relationship between the two variables in question. 
Figure 2. Revenue Capacity vs. Predicted Cost

119 Connecticut K-12 School Districts, FY2019

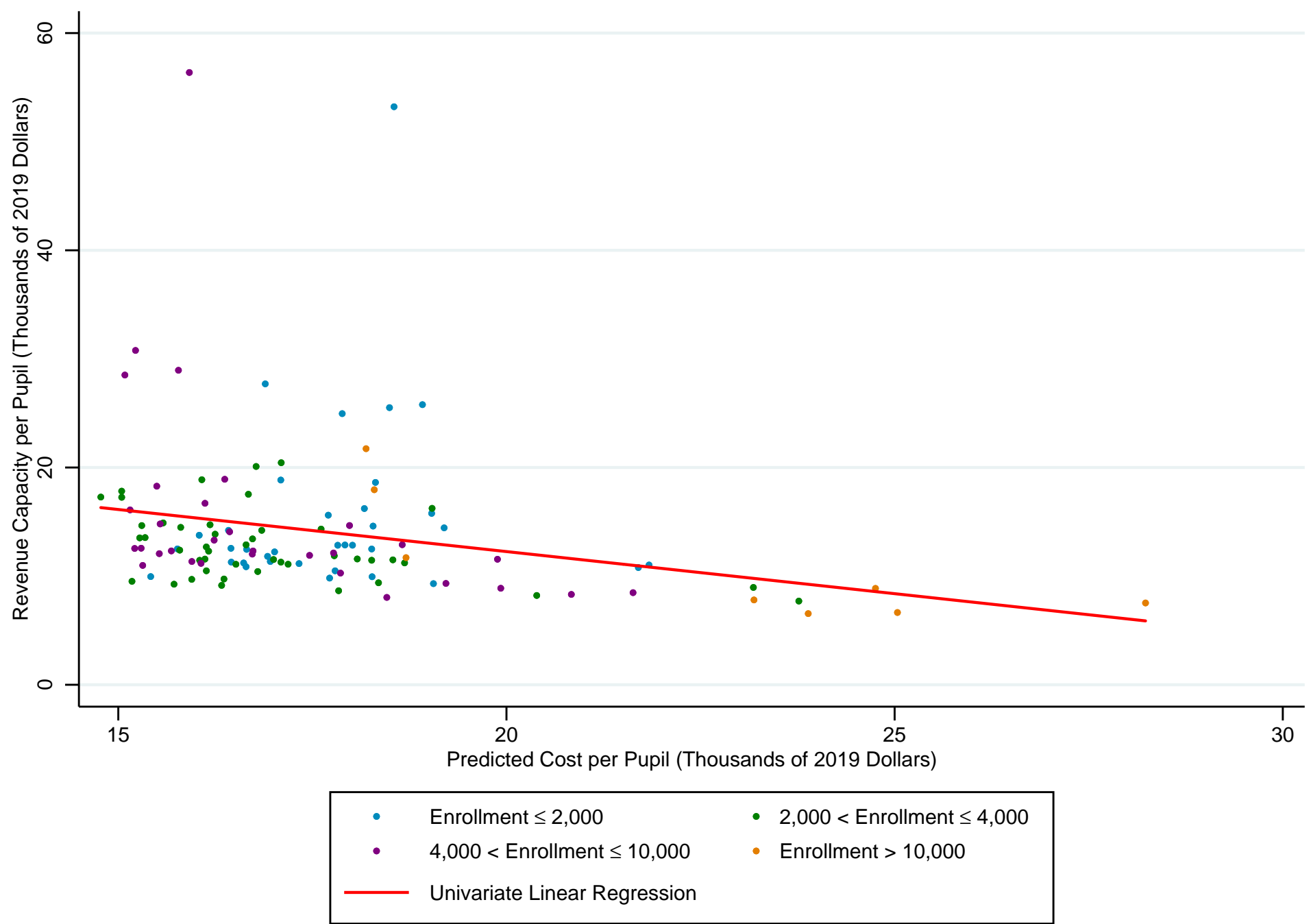

Source: Author's calculations

Notes: Property taxes are assumed to fund 55 percent of the statewide predicted cost. The student test performance target for each school district is assumed to be 61.5 percent of students meeting or exceeding the achievement standard. The red straight line is generated from a univariate regression that describes a simple linear relationship between the two variables in question. 
Figure 3. Existing State Aid vs. Cost-capacity Gap

119 Connecticut K-12 School Districts, FY2019

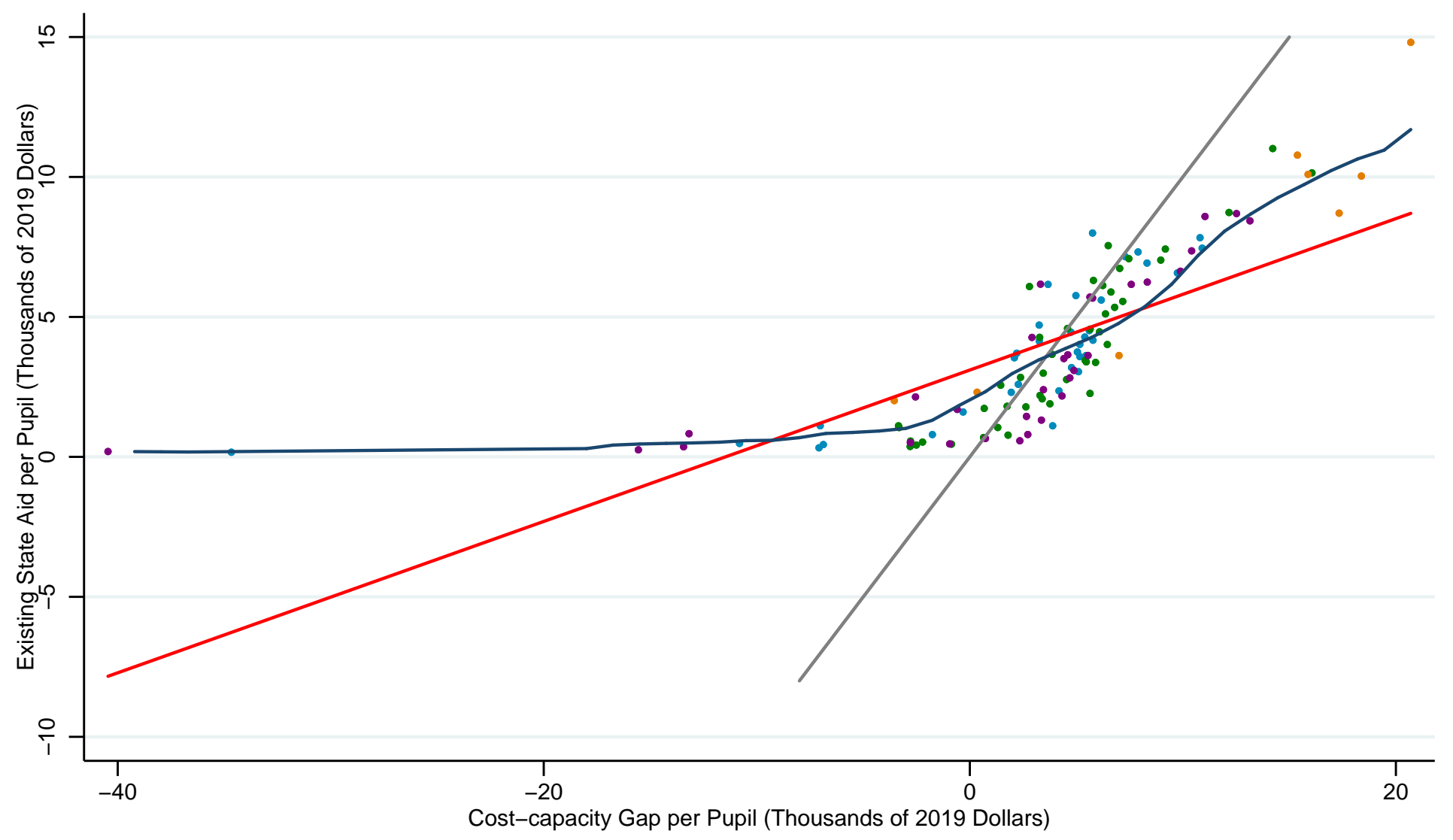

\begin{tabular}{llll|} 
Enrollment $\leq 2,000$ & $\begin{array}{l}2,000<\text { Enrollment } \leq 4,000 \\
\text { Enrollment }>10,000\end{array}$ & 45 -degree Line & 4,000 $<$ Enrollment $\leq 10,000$ \\
& Kernel-weighted Local-mean Smoothing
\end{tabular}

Source: Author's calculations

Notes: Property taxes are assumed to fund 55 percent of the statewide predicted cost. The student test performance target for each school district is assumed to be 61.5 percent of students meeting or exceeding the achievement standard. The red straight line is generated from a univariate regression that describes a simple linear relationship between the two variables in question. The blue curved line is obtained from the kernel-weighted local-mean smoothing using the Epanechnikov kernel and the default bandwidth. 
Figure 4. Kernel-weighted Density of Cost-capacity Gap and Post-aid Gap

119 Connecticut K-12 School Districts, FY2019

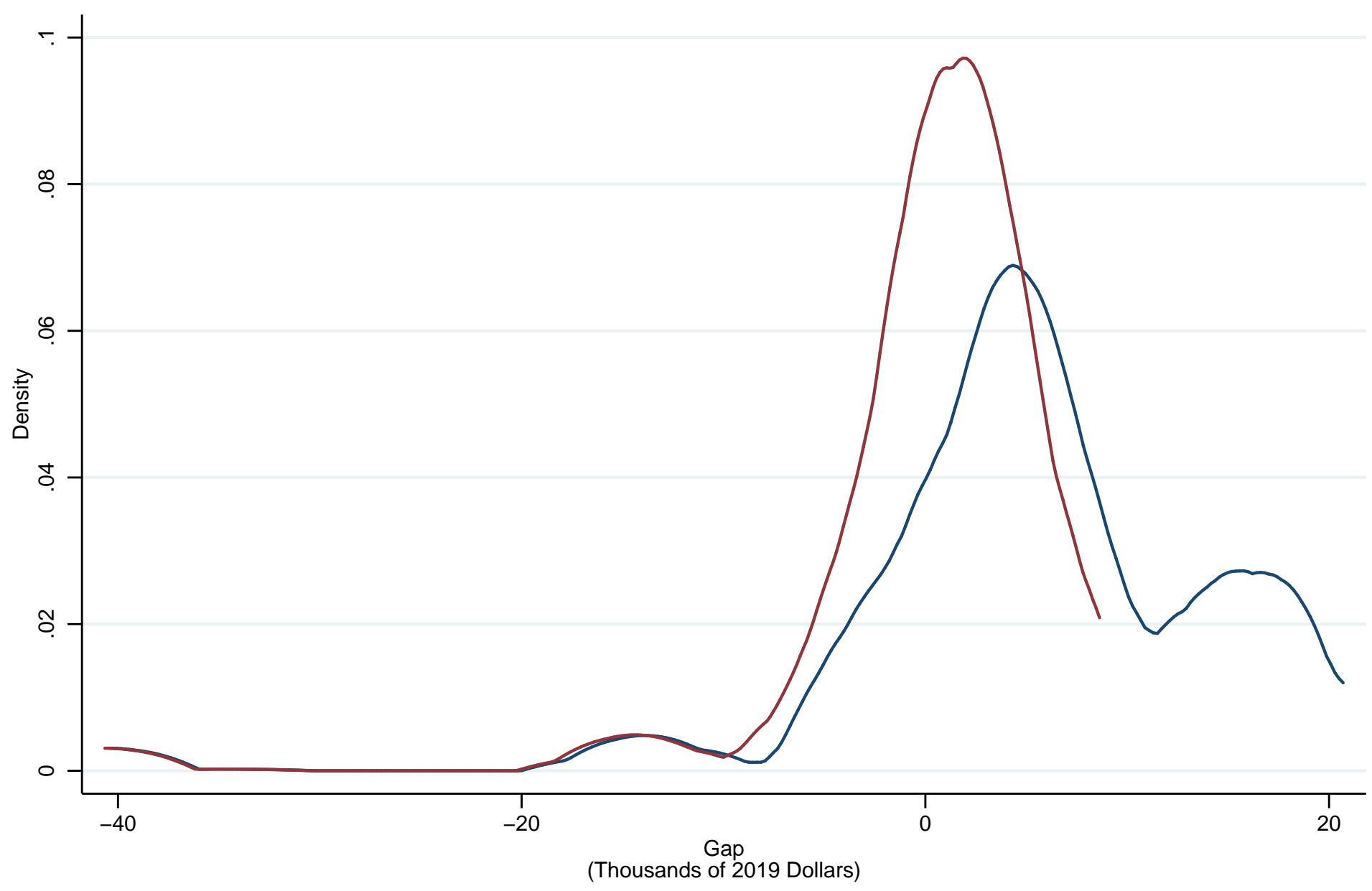

\section{Cost-capacity Gap — Post-aid Gap}

Source: Author's calculations

Notes: Property taxes are assumed to fund 55 percent of the statewide predicted cost. The student test performance target for each school district is assumed to be 61.5 percent of students meeting or exceeding the achievement standard. The post-aid gap per pupil is defined as the cost-capacity gap per pupil minus state aid per pupil. The Kernel-weighted density curves are obtained using the Epanechnikov kernel and the bandwidth of 2 . 
Figure 5. Existing and Gap-based State Aid Distributions (Part 1)

117 Connecticut K-12 School Districts, FY2019

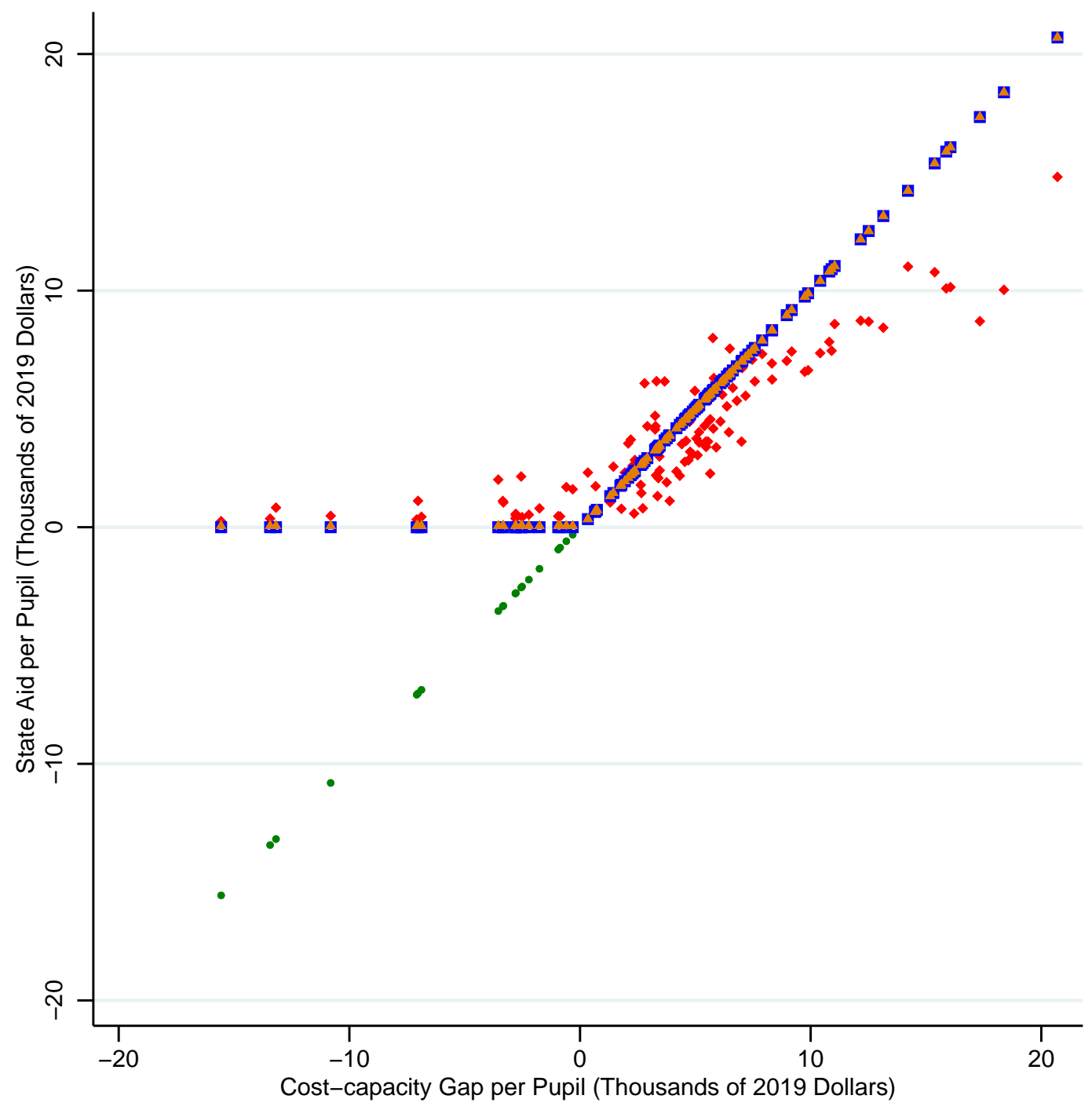

- Existing State Aid Distribution

- Gap-based Formula 1: Negative Aid to Negative-gap Districts

- Gap-based Formula 2: Zero Aid to Negative-gap Districts

$\triangle$ Gap-based Formula 3: Minimum Aid

Source: Author's calculations

Notes: Property taxes are assumed to fund 55 percent of the statewide predicted cost. The student test performance target for each school district is assumed to be 61.5 percent of students meeting or exceeding the achievement standard. Greenwich School District and Regional School District 12, which have a cost-capacity gap per pupil of close to $-\$ 40,000$ and $-\$ 35,000$, respectively, are excluded in order to preserve the scale of this graph. The minimum aid is set as $\$ 55$ per pupil. 
Figure 5. Existing and Gap-based State Aid Distributions (Part 2)

117 Connecticut K-12 School Districts, FY2019

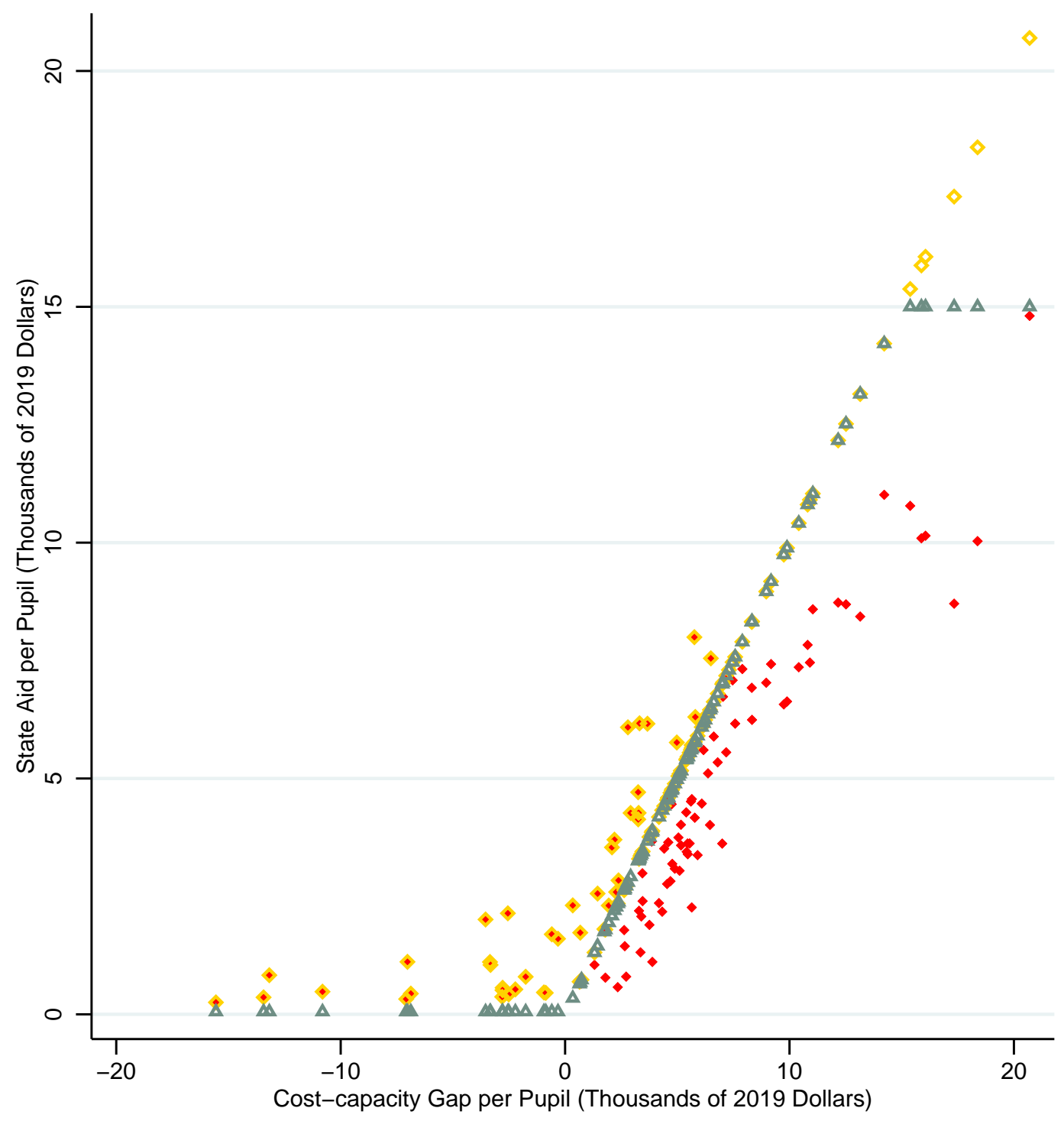

- Existing State Aid Distribution
$\Delta$ Gap-based Formula 4: Holding Existing Aid Harmless
$\Delta$ Gap-based Formula 5: Minimum Aid and Maximum Aid

Source: Author's calculations

Notes: Property taxes are assumed to fund 55 percent of the statewide predicted cost. The student test performance target for each school district is assumed to be 61.5 percent of students meeting or exceeding the achievement standard. Greenwich School District and Regional School District 12, which have a cost-capacity gap per pupil of close to $-\$ 40,000$ and $-\$ 35,000$, respectively, are excluded in order to preserve the scale of this graph. The minimum aid and maximum aid are set as $\$ 55$ per pupil and $\$ 15,000$ per pupil, respectively. 


\section{Appendix Figure 1. Existing State Aid vs. Predicted Cost \\ 119 Connecticut K-12 School Districts, FY2019}

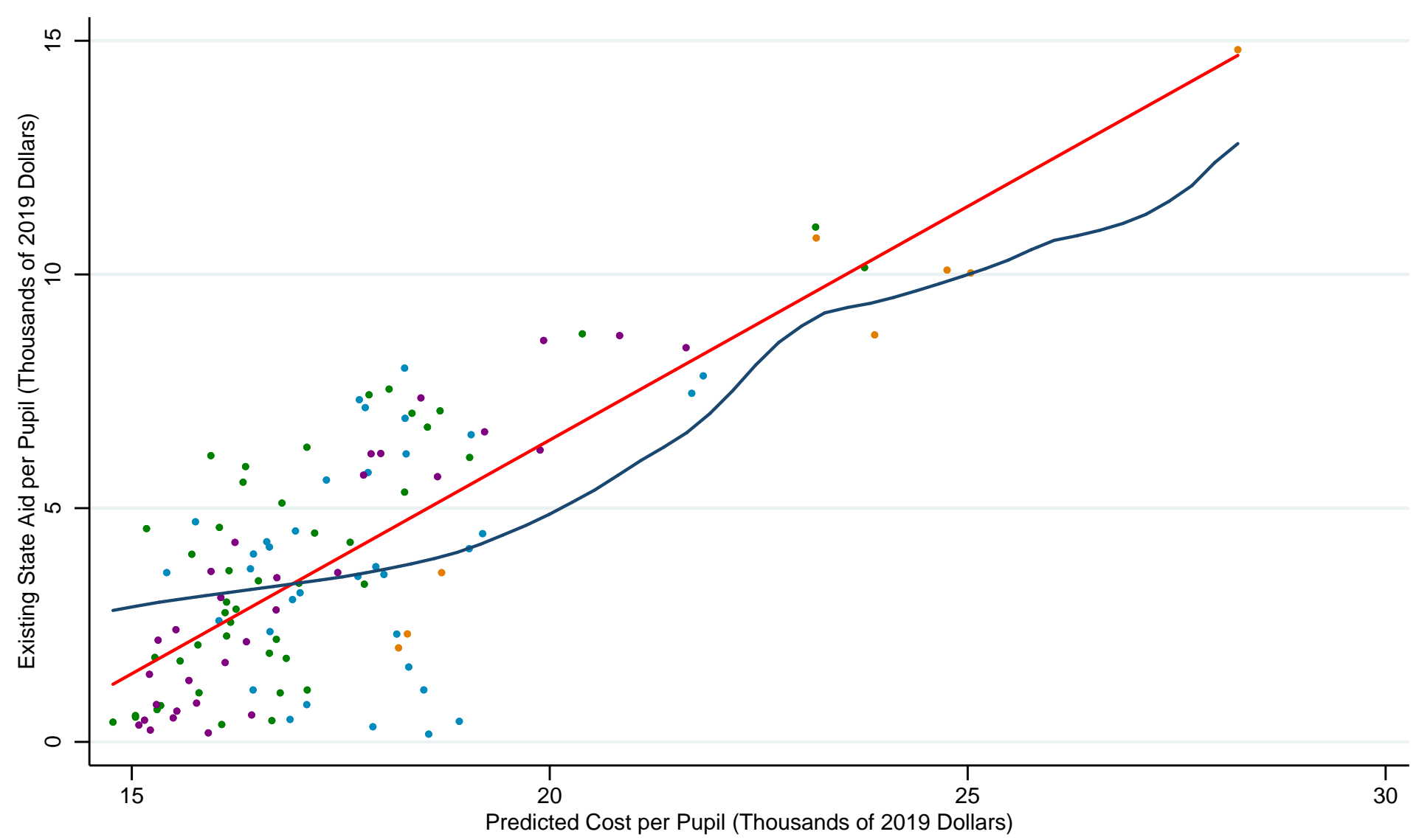

\begin{tabular}{|c|c|c|c|}
\hline - & Enrollment $\leq 2,000$ & - & $2,000<$ Enrollment $\leq 4,000$ \\
\hline - & $4,000<$ Enrollment $\leq 10,000$ & - & Enrollment $>10,000$ \\
\hline
\end{tabular}

Source: Author's calculations

Notes: The student test performance target for each school district is assumed to be 61.5 percent of students meeting or exceeding the achievement standard. The red straight line is generated from a univariate regression that describes a simple linear relationship between the two variables in question. The blue curved line is obtained from the kernel-weighted local-mean smoothing using the Epanechnikov kernel and the default bandwidth. 


\section{Appendix Figure 2. Existing State Aid vs. Revenue Capaciy \\ 119 Connecticut K-12 School Districts, FY2019}

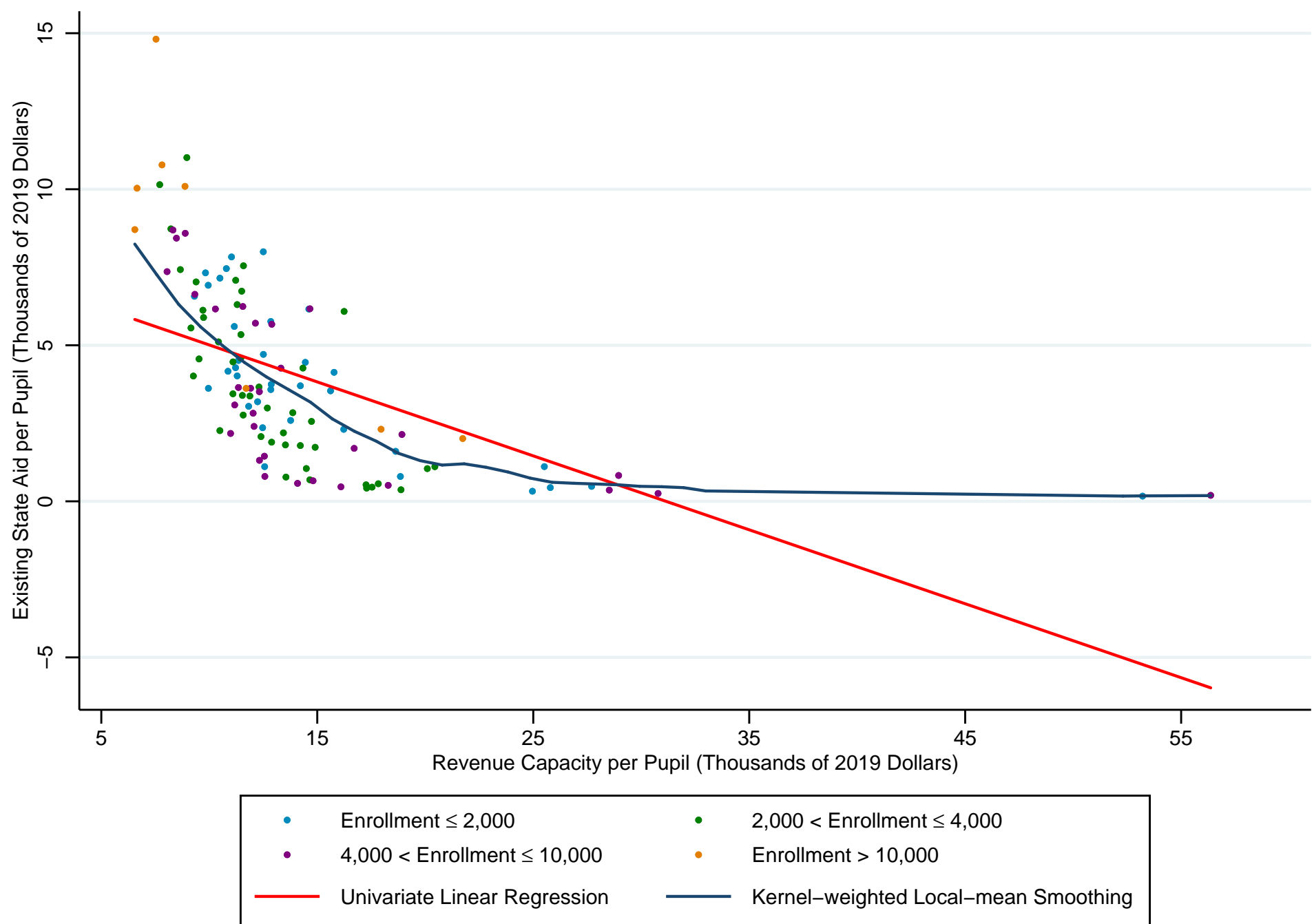

Source: Author's calculations

Notes: Property taxes are assumed to fund 55 percent of the statewide predicted cost. The student test performance target for each school district is assumed to be 61.5 percent of students meeting or exceeding the achievement standard. The red straight line is generated from a univariate regression that describes a simple linear relationship between the two variables in question. The blue curved line is obtained from the kernel-weighted local-mean smoothing using the Epanechnikov kernel and the default bandwidth. 